\title{
Chapter 3: Around the Series of Articles Życie w USA [Life in the USA]
}

\section{Introductory Remarks}

Under the pseudonym Jan M. Nowak, ${ }^{253}$ Miłosz published in Odrodzenie a series of twenty articles on society entitled Życie w USA [Life in the USA], with the subtitle From a special correspondent of Odrodzenie. The installments, varying in length, were published at irregular intervals within the space of one year. The first (in December) was printed in the last issue of 1946, while the final one (in November) in issue 43 of 1947. Installment twenty-one, which would have appeared in 1948, was withdrawn at the request of the author. ${ }^{254}$ Correspondence with Karol Kuryluk does not explain why the series was discontinued. A possible reason seems to be his dismissal from the post of editor-in-chief in February 1948. Another reason may be Miłosz's encounter with the community of politics in mid-1947, and his disappointment with Wallace, the editor of The New Republic, a biweekly which was one of the main sources of the topics covered in the series. In 1947, Dwight Macdonald, under whose influence Miłosz was by then, penned a damning characterization of Wallace. ${ }^{255}$ Another reason could be that Miłosz's choices were crystallizing - the last episode of the series clearly refers to the completed Traktat moralny [Treatise on Morals].

In addition to the texts signed Jan M. Nowak, the diplomat also sent in articles written under the pseudonym Żagarysta ${ }^{256}$ and under his own name. ${ }^{257}$ This was not the first time for him as a correspondent. In the United States, his situation was different than in pre-war France, from where he also sent articles - experienced with

253 See Stownik pseudonimów pisarzy polskich XV w. - 1970 r. [Dictionary of Polish literary pennames - 15th Century to 1970] Jankowski, Edmund et al. (eds.) Wroclaw, 1995, vol. 2, p. 705. Nowak's identity remained unknown for so long that neither Jacek Natanson (see idem Tygodnik Odrodzenie 1944-1950, Warsaw, 1987) nor Wiesław Paweł Szymański (see idem: Odrodzenie $i$ Twórczość $w$ Krakowie (1945-1950), Wroclaw, 1981) mention the series Życie w USA, or its creator.

254 His manuscript is kept in the Adam Mickiewicz Museum in Warsaw, collection issue 4, call no. 4135.

255 Macdonald, Dwight: "Henry Wallace (Part 1)," politics 1947, March-April, pp. 1-38; "Henry Wallace (Part 2)," politics 1947, May-June, pp. 96-117. These articles were the basis for Miłosz's analysis in "Henry Wallace w opinii amerykańskiej" [Henry Wallace in the American Opinion] of Feb. 2, 1948. AMSZ, DPI, c. 21, b. 82, f. 1108, pp. 101-109.

256 These are the essays "Książki i pisma w Stanach Zjednoczonych" [Books and Journals in the United States] and "Zabawy i spory" [Games and Arguments].

257 These are the features and essays "Abstrakcja i poszukiwania" [Abstraction and Searching], "Massachusetts", "Na Independence Day” [For Independence Day], "Faulkner”, "Henry Miller, czyli dno" [Henry Miller or Rock Bottom]. Miłosz also published his new poems here, and he occasionally reviewed theatrical plays. 
war, he was here as a regime official, writing about a country belonging to a competing political bloc, and the sources of his reports were more diverse. This had an impact on his style, choice of material and manner in which it was discussed.

At the time, the role of a correspondent from across the Atlantic was not an easy one: more and more propaganda about the West, and in particular about the United States, appeared in the Polish press. Attempts to represent America objectively were risky. In turn, any justified criticism - since there was no access to information or possibilities to verify its credibility - might expose one to accusations of propagandizing from the circles opposed to the system. Jerzy Jarzębski comments on this as follows:

Of course, one might doubt the sincerity of this criticism of the New World: ultimately it could have been due in part to the political choices Miłosz made at the time, which demanded confirmation by means of the somewhat ritual gesture of rejecting America. But he repeated his criticism several years later at Berkeley, so it seems that he never achieved full acceptance of the New World, even though he did change his mind on many issues. ${ }^{258}$

Miłosz was aware of how delicate a mission he was undertaking, creating a series of this sort in the years of growing tensions in the relations between the USA and the USSR. Sometimes he vented his impatience, engaging in polemics with the editors of Kuźnica, which he also published under his own name:

\begin{abstract}
You can say very unpleasant things about the United States. It is interesting to note that those who fire at the US usually miss the most. Both listening to foreign radio stations and browsing the American press give American journalists a great deal of very entertaining material, which is often printed here with no comment, and the reader, roaring with laughter or fuming with indignation - depending on his disposition - no longer needs to be convinced that the rest of the world is barbaric and hypocritically bent, and let us note that such a chauvinistic mentality is hardly conducive to international cooperation. Writing that in New York people have to stand in long lines to buy bread (in one of the most prosperous periods in US history), or that demobilizing soldiers are destitute (the draft budget submitted to Congress by the government provides a twelve-digit sum for veteran education in schools and universities) or arguing that there is a Negro hanged on every tree - these would be examples of such firing and missing. ${ }^{259}$
\end{abstract}

Under these circumstances, the use of a pseudonym was probably a prerequisite to inform the public - as far as censorship would allow - about American politics, economy, culture and customs. Odrodzenie and Kuźnica published other correspondence from the USA, sent by Ilya Ehrenburg, Aleksander Janta-Połczyński, and Aleksander Hertz. These articles provided some of the context for Miłosz's series - he engaged in polemics with some of the authors writing for these magazines. The

258 Jarzębski, Jerzy: “Obrazy Ameryki w Świetle dziennym Miłosza” [Images of America in Miłosz’s Daylight], Ruch Literacki 2012, issue 3, p. 296.

259 Nowak, J. M. [Miłosz, Czesław]: Życie w USA, Odrodzenie 1947, issue 7, p. 9. 
poet proposed his own pseudonym, but the editor of Odrodzenie managed to dissuade him: "The pseudonym I put in is different than what you suggested, more appealing to the average Pole: 'J. M. Nowak' - an average person. I know that the first article aroused enormous interest and attracted a great deal of attention" (Zaraz po wojnie [Right after the War], 573). By choosing a popular surname, Kuryluk puts Miłosz in an everyman costume, at the same time emphasizing his alien status in the New World. It is not known whether or not the name was meant as a reference to the figure of Jan Nowak-Jeziorański.

Writing under a pseudonym could help the poet hide from his superiors and opponents - this would follow from the letter dated February 10, 1948. Asking for the publication of one installment, the poet explains: "The reasons are related to my diplomatic status and are serious - both public and private. I do not wish to dwell on them, you will guess what they are yourself, if you take into account that Nowak's identity is doubtful to certain circles, as I have recently learned."260 On the other hand, he guided his readers to the right trail himself, referring to a stay in France, or writing stinging comments about the authors of Kuźnica that all but revealed who their author might be. Other reasons may be indicated for using a pseudonym. In addition to the correspondence for Odrodzenie, Miłosz sent regular official reports to the Ministry of Foreign Affairs. As a diplomat, he might have been reluctant to appear as a columnist. In a report for the Ministry of Foreign Affairs, he deftly defended himself against allegations of cooperating with Kuryluk in secret: "I supply the editorial team of Odrodzenie with short articles covering the most important events in America and other materials (e.g. Wallace's letter). ${ }^{261}$ For the magazine Twórczość, I obtained the right to print two American literary essays (on Caldwell and Steinbeck), written by [Wilbur M.] Frohock, a professor at Columbia University." 262

Although the articles touch on similar subjects, the author did make the effort not to disclose the common identity of the diplomat and the correspondent. Reading the reports confirms the poet's later statements that he wrote bravely, and his reports were not - to use his own language - combed flat. A letter from Aleksander Jackowski, deputy director of the Press and Information Department at the Ministry of Foreign Affairs, contains an admonition:

Unfortunately, we must say that this report departs significantly from the reports that cultural attachés are accustomed to sending. There is no word in it about the essence of the work of the

260 Letter of Czesław Miłosz to Karol Kuryluk, of Feb. 10, 1948 roku, Nowa Dekada Krakowska 2013, issue $1 / 2$, p. 15.

261 This is Wallace's open letter to the president of the United States. After a series of speeches criticizing the foreign policy of the Truman administration, it was the direct reason for Wallace's dismissal from the post of Secretary of Commerce.

262 Report of the Activities of Czesław Miłosz, Cultural Attaché at the Polish Embassy in Washington for Nov. 1 - Dec. 1, 1946. AMSZ, DPI, c. 21, b. 86, f. 1171. 
Attaché's Office, its activities, meetings with important figures in literary and scientific spheres. The report does not cover at all a characterization of the predominant moods, or the cultural and educational activities conducted among the American Poles. Nor does it cover the issue of propagating Polish culture in the United States. ${ }^{263}$

The freedom with which Miłosz described the beginnings of the Cold War, the position of communists in the USA, and the knowledge he used in evaluating the policy of the Soviet Union, all demand that his analyses be treated with attention. The poet did not hide the fact that he enjoyed the freedom of expressing his opinions in official letters. He wrote to Matuszewski: "I like writing reports for the Ministry of Foreign Affairs in general, because they give me much more freedom in presenting the situation objectively" (Zaraz po wojnie, 404).

It would seem he enjoyed less freedom in his literary essays. A comparison of his reports with Życie w USA shows the latter in the appropriate light. The content of the series is reduced: fewer issues are addressed here, and comments on them are less extensive. What is more, Miłosz clearly separated these roles on various levels, hence the decision to divide both these very different modes of discussing American news also at the level of the signature. However, it would be mistaken to think that in the diplomatic reports he shared his full knowledge. On the contrary! As a reader of politics and Partisan Review, Miłosz kept to himself a deeper understanding of the history and politics at the time, carefully selecting his secret reading list, which will be mentioned only after the publication of The Captive Mind, and Native Realm, but in the meantime he perfected the strategy of concealment and discovery. One can verify this on the basis of the texts in which he reevaluates the American postwar period, and particularly in $A$ Year of the Hunter, where he returns to the beginnings of his acquaintance with the organizers of the Congress for Cultural Freedom.

He wrote them as an intellectual shaped not at the embassy desk, but in the heat of debate of Macdonald's editorial office. Miłosz, who is in the circles of the New York and Washington intellectual elite, knows more about America than he is willing to reveal at the time. How do we know this? Not from his letters, articles, or reports, but from indirect sources: the forms and compositions used in his journalism, his reading choices, his translations, and the allusions he makes later in his articles for Kultura. In America, Miłosz is a poet seeking for himself the most distant horizon possible, at the same time showing a closer horizon to those unable to keep up. Życie w USA delineates the limits of such a circle of initiation, which he himself regarded as elementary and operational; for him, however, decidedly too small.

What does this separation of roles in the reports and essays in fact consist in? The reports, although they do not contain elements of literary imagery, have a journalistic nerve and are characterized by considerable freedom in their choice

263 AMSZ, DPI, c. 21, b. 87, f. 1182. 
of subjects. In the articles for Odrodzenie, paradoxically, it is easier to notice selfcensorship or setting up false trails. First of all, the author does not duplicate his topics and sources. With acrobatic caution, he avoids quoting the same papers, journalists, or using the same data and opinions. Only in a few situations can one see a convergence of the diplomat and the correspondent - he sometimes comments on the same satirical drawing, book or exhibition. Secondly, in the face of antiAmerican propaganda, he does his best not to present those attacked by the press in an uncomplimentary manner. This applies above all to President Truman, who is referred to in sharp words in the reports - the mildest of his descriptions in the reports is "[a man of] fairly modest intellectual qualifications," ${ }^{264}$ while in the series he tries to show his virtues as a political player and advocate of social reform. He tones down the Polish discussion about racism, does not reveal critical judgments about the Polish diaspora. In other words, with issues which he considers to be in need of a more circumspect treatment, he is more diplomatic. This choice of attitude was dictated by the conviction that, despite tense political relations, nations can and must be brought closer together through cooperation on the cultural level. Although many times the correspondent allows himself free reign in his diatribes on American topics, they all share a common goal - that of demythologizing the New World, which in the collective consciousness tends to take on an idealized form. Thirdly, the political analyses of the reports are shortened and simplified in the series, deprived of their most important and most interesting observations, indeed, sometimes their very directions diverge. This happens in his assessment of the position of communists and the political role of trade unions - if the author of the reports harbors no illusions about the future of communism in America, Wallace's career or the outcome of the disputes between trade unions, the correspondent provides the information as if he were unaware of it all. The analyses in the series are structured in such a way that they seem to be written spontaneously, without sufficient discernment - while they have reliable counterparts in the reports.

The matter of authorship is a separate issue. Miłosz claimed that the consulate tried to put him in the role of a figurehead, and his job was to read and summarize the press:

(...) To you, sir, I can explain what my role was when I was in America. This was the role of a correspondent of the Polish press, masked, well, not so much masked, as sitting there ostensibly as a diplomat. (...) In fact I felt obliged to act as a correspondent. And indeed, what can be said now is that my real role was that I sat there, reading the American press eagerly and... in Warsaw they did not care for any 'polite' reports, ones that were sort of combed flat. They just did not have any information about what was going on in America. (...) And they were actually satisfied

264 Raport sytuacyjny o nastrojach na terenie działalności Konsulatu Generalnego w New Yorku za okres 1 IX - 30 IX 1946 r. [Situational Report on the Moods in the Area of Operations of the New York Consulate for the Period from Sept. 1 to Sept. 30, 1946]. AMSZ, DPI, c. 21, b. 87, f. 1182. 
when I wrote without any censorship, without beating around the bush, all that could be inferred from the American press. This is what my role was (Autoportret przekorny, 113-115).

The poet saw himself as someone who should build bridges between Poland and America. He particularly liked his position as a press correspondent. In his memoirs, not only does Miłosz not talk about the series, but he claims "Under normal circumstances, my articles would appear on the front page of the paper. And these were reports that only went to the Ministry of Foreign Affairs" (Autoportret przekorny, 116). Meanwhile, two episodes of the series did appear on the front page of the magazine, and several others on the second or third. Miłosz's activity significantly exceeded the scope of his duties, but the sources of his knowledge were mainly reading and conversations. It is easy to understand the motivations of the correspondent who, using other people's analyses, passes them on under a pseudonym. Sometimes he refers to specific press and book titles, and names of eminent analysts or journalists. These are, for example, reports from special committees of the Congress, Senator George Meader's report on the stationing of American troops in Germany, The Nation journalist Fritz Sternberg's book The Coming Crisis, ${ }^{265}$ polls and ranking lists of Fortune, comments from PM's Ralph Ingersoll's and Commentary's Dorothy Thompson, and statistical reports from the international magazine United Nations World. In most cases, Miłosz synthesizes and compiles analyses and evaluations from many sources which he does not disclose, so the problem of authorship could be signaled here. On the one hand, it all seems obvious: Miłosz called the work into being, devised it and executed it. On the other hand, he constantly used such statements as: "the American press has revealed," "as the press claims," "the American press devotes a good deal of space," "the majority of the press says," "it is said," "from the local press you may find out" etc., stressing that his role is a secondary one. He justifies it in issue 7 of Odrodzenie:

\begin{abstract}
European journalists coming to the United States are unanimous in their agreement that to gain at least some understanding of the country's intricate economic and political structure, even those who speak fluent English would need one to two years. A short stay usually provides nothing; one's first impressions are wrong, plus or minus, because the journalist who comes for a short time is at the mercy of his interlocutors, or lack thereof, more or less as an American journalist coming to one of the European countries. ${ }^{266}$
\end{abstract}

Apart from the desire to conceal his real competences, Miłosz may have had another motivation - potential criticism of some aspects of life in the United States could not be attributed to the author, because in most cases it was a quotation of opinions circulating in American public opinion. This question could be important for Miłosz.

265 See Sternberg, Fritz: “Prosperity - How Long Will It Last?,” The Nation 1947, issue 13, pp. 307308.

266 Nowak, J. M. [Miłosz, Czesław]: Życie w USA, Odrodzenie, 1947, issue 7, p. 9. 
Since he could not avoid being critical or touching on delicate issues, he put himself in the role of someone who quotes, paraphrases and summarizes the opinions of others. From the perspective of his later work, it can be concluded that $\dot{Z} y c i e w$ USA is a silva rerum of sorts. In its hybrid genre and style, clear measures are taken to make the forms of subsequent episodes attractive to the reader: anecdotes are used, along with quotations, satirical descriptions, tables with statistical information, quantitative comparisons, a quasi-letter, and a text in memoriam. The author builds a plane of understanding based on conversational phrases and humorous punch lines. In view of its choice of subjects, their arrangement in threads, and their style, the series should be recognized as part of Miłosz's work, which does not invalidate the questions about the degree to which he identified with the views he reported.

Letters from Kuryluk and the comments on them in Zaraz po wojnie indicate that the interested parties had agreed on the issue of discussing politics. Already in 1947, the poet clearly separated matters of politics and culture. If in the letter attached to the translations of Negro spirituals he concludes perhaps not entirely convincingly, "I believe that the culture of a nation should not be mixed up with politics. If it were, the Russians, for example, would not have published the entire work of Whitman or Hemingway in their country." ${ }^{267}$ In another letter, he encourages the editor, "Do not worry too much about the political situation and keep your cool in writing, if I may advise you. Spreading panic and propaganda against both sides is a disservice to humanity. ${ }^{268}$ The editor did not put any pressure on the poet - he asked for articles about American literature and culture. At any rate, there was no occasion for this Miłosz complains almost in every letter about problems with contacting Kuryluk, the sluggishness of the postal service, and he expresses impatience over not receiving any confirmation that his correspondence had reached the addressee. ${ }^{269}$

Another issue is the possibility that changes were made in the series. In the second half of the 1940s, the Central Censorship Office for the Press, Publications, and Performances [Główny Urząd Kontroli Prasy, Publikacji i Widowisk] subordinated all areas of public life to itself, acting according to the tried and tested Soviet models:

In addition to controlling texts at many stages, the Office also supervised the administrative side of the operation of printing houses. Registration of machines, printing devices, and published works, unification of the register of orders, full decision-making regarding press concessions all these activities were the domain of the growing institution.

The work of censorship (...) was divided into four stages: initial, factual, subsequent, and secondary control. Licensed periodicals were exempt from the first phase. The second stage,

267 Letter of Czesław Miłosz to Karol Kuryluk, not dated, op. cit., p. 12.

268 Letter of Czesław Miłosz to Karol Kuryluk of 25 November 1947, op. cit., 10.

269 Letter of Czesław Miłosz to Karol Kuryluk of October 27 1947, op. cit., p. 9. In the Desiderata of the Cultural Attaché Miłosz intervened about the functioning of the postal service which adversely affected cooperation between publishers and institutions of science. 
finalized with a permission for printing, concerned all copies checked with the entire circulation to be distributed. During the secondary control, it was the work of the censors themselves that was under scrutiny, subject to ideological assessment, and instructional conclusions were formulated for the future. ${ }^{270}$

Kuryluk's magazine was subject to the same procedures. Nevertheless, Odrodzenie was not an agitational magazine. Researchers of varying attitudes to the Polish People's Republic stress the moderation and restraint that the editorial board was able to maintain in political matters. This was probably why Miłosz sent his correspondence to the magazine. As he recalls:

The postwar Kuryluk did not enjoy a good opinion among hardcore Communists, as can be seen from the way he was mentioned in Putrament's letters. It was thought that he was not sufficiently combative, too cultured. As an editor, he tried to be self-reliant and independent in his judgments. The Krakow times of Odrodzenie were prosperous for him. He found valued collaborators and allies there, including Kazimierz Wyka. ${ }^{271}$ The transfer of the editorial office to Warsaw in 1947 meant daily interference from Borejsza, which finally led to clashes with him, when Kuryluk did not surrender, and resigned (Zaraz po wojnie, 569-570).

The poet took great care about the form of the publication - he gave detailed instructions on the font, number of columns, neighborhood of other texts, and placement of the photographs. Also in correspondence with Kuryluk, he gives similar directions, especially in relation to his poems and translations. The letter attached to the article on the conference at Bread Loaf shows that Miłosz sent photographs to Odrodzenie, which he wanted to illustrate his essays - they were portraits of John Steinbeck and William Faulkner. He tried to avoid exerting any propaganda influence by printing his texts alongside other articles. In the correspondence, one also finds a request to delete from the essay a passage which after some time the author deemed unnecessary. It is clear that he was aware of the interference of censorship in his texts - in a letter of December 1, 1947, he draws attention to the exaggerated reworking of an article by his associate from Harvard into the Polish Galician dialect. So protective was the poet of his independence that when Odrodzenie was moved to Warsaw, and Jerzy Borejsza ${ }^{272}$ became its editor-in-chief, in his letter to Ryszard Matuszewski he presents an ultimatum concerning one of his essays: "Miłosz asks that it either be printed intact, or to not printed at all, if the former proves impossible, and he will

270 Gajda, Krzysztof: Cenzura. [Censorship]. In Stownik realizmu socjalistycznego [Dictionary of Socialist Realism], op. cit., pp. 32-33.

271 Kazimierz Wyka (1910-1975) a distinguished literary historian, literary critic and professor at the Jagiellonian University in Krakow.

272 Jerzy Borejsza (1905-1952) born Beniamin Goldberg, writer and communist propagandist; founder of publishing house Czytelnik, one of the largest and most influential presses in communist Poland. 
not be too distressed if, for censorship reasons, the article cannot be published in Odrodzenie" (Zaraz po wojnie, 404).

It would be best to reconstruct the sources based on which Miłosz formulated his judgments about America and to examine the very process of the formation - in the intellectual and literary sense - of this vision. The diplomat read many periodicals on a daily basis and could compile his opinions based on various sources. ${ }^{273}$ He did not need to read all the papers. It can be assumed that he used the press reports that were distributed at the embassy and the Ministry of Foreign Affairs by the Polish Research and Information Service, a special unit established for this very purpose. According to diplomatic correspondence, there were not enough officials in Washington to analyze the press. It seems that the poet understood well the rules of the new reality and did not put himself or Kuryluk in danger by expressing opinions that might be too unsettling in the eyes of the censors.

Miłosz repeatedly praised the diversity and overall level of American journalism. What is most easily reconstructed in the series is the corpus of the most frequently quoted magazines. In several cases, one can identify the source from which he drew his information and arguments: this applies to the sections devoted entirely to books by Fritz Sternberg and David Davidson, the review of the film The Best Years of Our Lives, the arms race, and the employment of German scholars, and when the author refers to personal experiences: traveling to Vermont and Virginia, reading H. G. Wells, or the lecture by Thomas Mann. Reviews of political information are most often a synthesis of articles from The New Republic and The Nation. He does occasionally happen to express thoughts suggesting that he read politics and Partisan Review they are mostly generalizations and questions about the possibility of building a new transatlantic civilization.

A matter of utmost importance was selecting the press material for his reports and for the needs of the series. As mentioned, wanting to remain incognito, the correspondent selected his sources for Odrodzenie in such a way that they did not coincide with the sources used in his official analyses. In the latter, he readily used The New York Times, New York Herald Tribune, and Saturday Review entirely omitted in the series, which in turn referred to titles that were almost unused in the reports.

273 The following newspapers were at the disposal of the employees of the Attaché's Office: The New York Times, New York Herald Tribune, New York Post, Daily Worker, The Washington Post, The Times Herald, Washington Daily News, Evening Star, Chicago Daily Tribune, St. Louis Dispatch, Gazette and Daily, The Christian Science Monitor, Baltimore Sun, The Wall Street Journal, The Times of London, Nowy Świat, and Dziennik dla Wszystkich. In addition, the following magazines were available: Time, The New Yorker, The Nation, The New Republic, U.S. News and World Report, Saturday Evening Post, Harper's, United Nations World, Foreign Affairs, Foreign Policy Reports, Foreign Policy Bulletin, American Perspective, World News Letter, Report on World Affairs, In Fact, Marshall Plan Letters, and Gtos Ludowy. 
This game, played with his superiors in Poland, was not, as one may imagine, viable in the long run...

One of the titles he mentions most frequently is The New Republic - Miłosz describes it as "democratic" 274 and uses it, which is otherwise rare, both as a diplomat, and as a journalist. Its editor from December 1946 was Henry A. Wallace, a leading politician of the progressive faction of the Democratic Party - precisely when the publication of the series was begun. Despite his initial sympathy for the revolution in Russia, skeptical attitudes towards the USSR deepened during the Cold War in the magazine's editorial office. Wallace, dismissed by President Truman as secretary of commerce, used his position in the paper to attack the administration's foreign policy. He considered the announcement of the so-called Truman Doctrine as the beginning of the century of fear. Negative assessments of Soviet communism in The New Republic appeared only appeared in 1948, after Wallace's departure. His resignation was dictated by his decision to run for office in the presidential election on behalf of the Progressive Party. Życie w USA contains many traces of The New Republic, from interest in the formation of the Progressive Party and the situation of trade unions to the evaluation of the policy of the Truman administration.

Another paper that Miłosz referred to was P.M. - in the reports he calls it a leftist magazine. This New York daily featured texts by journalists with radical views, including members of the Communist Party (CPUSA), which led to it being accused of propagating communism, especially since the paper openly argued with the official left-wing Daily Worker. P.M. was distinguished by a relatively large number of photographs, satirical drawings and cartoons for a newspaper at the time. The correspondent describes political cartoons - their source may have been P.M. or The New Republic. Miłosz also shared with the readers his reading of Foreign Affairs. Its leading journalist in the 1940s was Dorothy Thompson, whose name he mentioned when discussing the election reports in Poland. This magazine played an important role in the first years of the Cold War, especially after the publication of George Kennan's "Long Telegram."

The correspondent made occasional references to The Nation, which in the 1940s was more left-leaning than The New Republic, and also to Fortune. He read the sensationalist tabloid Daily Mirror, and at the same time also The Christian Science Monitor. Sometimes he reached for United Nations World, Science and Society, Saturday Review of Literature, New Foundations, Political Affairs and Mainstream and Masses. In his memoirs, Miłosz returns to his familiarity with the circle of politics. From reports we know that he also met journalists of The New York Times, as well as Gertrude Samuels of the New York Times Magazine. Such a selection of newspapers, magazines, and acquaintances can be considered consistent - among the magazines read by the poet before the war, one of the most important ones was the leftist monthly

274 Nowak, J. M. [Miłosz, Czesław]: Życie w USA, Odrodzenie 1946, issue 51/52, p. 10. 
titled Miesięcznik Literacki. The poet's friends, among them Robert Lowell and Randall Jarrell, also read these magazines and published poems and reviews there.

To determine whether any changes related to censorship were made in the series, it would be best to compare the published texts with the manuscripts - many of them, however, are missing or are located in places that are not easy to find. We are dealing here with the problem of a postcolonial archive, i.e. one that is scattered and incomplete, and cannot be reconstructed, ordered or merged. It is also worth pointing out other problems in attempts to reproduce Miłosz's views on the matters he described. One cannot and need not marginalize his comments on American politics just for the reason that the subject of power always fascinated him. It should be stressed once again that there are discrepancies between the statements made by the correspondent, the diplomat, and the convictions of the poet.

Miłosz's special position as the author of the series deserves particular attention. On the one hand, he has the characteristics of an intellectual immigrant from Central Europe. This provides for a very beneficial, but also very risky, cognitive situation an observer from outside the system often notices in it what its creators fail to see, although he may also create nonexistent connections between the phenomena in it. On the other hand, using the arguments of journalists, politicians and economists, Miłosz presents an internal view on the country's current affairs. As he playfully commented: 'It was not American diplomats, but a 'Red,' who disseminated in his correspondence information on intellectual America, otherwise so little known to Europe at the time" (Native Realm, 296). Combining both attitudes, he turned them into an attractive way of presenting knowledge to an audience interested both in an emigrant's impressions and in factual knowledge. It might seem that Miłosz's main intention was to fill gaps in the reader's knowledge of American culture and society. He focuses on observable phenomena; he is interested in short-term processes that may be encapsulated in simple models. He assumes that the relationships between facts and phenomena that he describes exist, since others write about them. He does not address political and cultural processes in longer cycles. Calling himself a correspondent, Miłosz tries to be one in the full sense of the word. Not only does he play the role, but also makes it his subject. He points out, for example, the difficulties associated with it. In April 1947, he observes, “The US is a country in constant motion, a month sometimes means more than whole decades in static and unchanging civilizations. This is worth remembering, lest one fall into the traps set by amateurs of generalization, who try to 'define' America with a witty adage." ${ }^{275}$ This was meant as a means of endowing the identity of Jan M. Nowak with more credibility, and removing any suspicions as to whether the correspondent and diplomat might be the same person.

275 Nowak, J. M. [Miłosz, Czesław]: Życie w USA, Odrodzenie 1947, issue 10, p. 6. 
The title of the series ensures an optimum level of generality, so that it may contain wide-ranging observations. Whose life is described here? An emigrant's, or a country's seen through the prism of individual fates, the situation of ethnic, racial and social groups? The author tries to reconcile the personal perspective here - that of a resident, observer, reader, traveler, viewer, listener, and one who attends cultural events, with the viewpoints taken from authors, journalists, politicians and other interlocutors. This attitude is also connected with his belief in the possibility of a comprehensive and at the same time non-amateurish understanding:

In times when description of countries and civilizations was not demarcated by a multitude of prohibitions resulting from the division of knowledge into separate drawers, authors, usually travelers did not underestimate the time that froze solid in the slope of a roof, in the curve of a plow's handle, in the gesture, and in the proverb. The reporter, the sociologist, and the historian could coexist then in one person, before they all separated, to everyone's detriment (Native Realm, 165).

\section{In the Sphere of Politics and Economics}

Shaped as he was by the realities of interwar Poland, Miłosz initially perceives the living conditions and policy of the United States through the prism of those back at home. Much of how he assessed social and economic reality before 1939 is found in his occupation essays. Życie w USA owes a great deal to the Legends of Modernity, in which he interpreted literature as a commentary to the situation in Europe at the turn of the twentieth century. He treats it as a source of knowledge about the world that is not inferior to academic studies. What connects it to the article series is his desire to find links between the individual and the collective, fluctuations between the private and public, to study the instincts and passions that push the individual and the masses to action. Political, social and economic processes are to him the surface of much deeper processes, an emanation of the heart of darkness. If he says about Balzac that he took pleasure in describing insanity, he himself goes from the level of current news to considerations about the demon shaping history. ${ }^{276}$ On the other hand, his thinking has much in common with the reasoning of intellectuals in Western Europe who - like Emmanuel Mounier - wrote about "white violence" affecting the victims of capitalism. ${ }^{277}$

In the very first installment, Miłosz says: "In America there is a theory of selfregulation of the market, and all deficiencies have been attributed to artificial control,

276 Numerous mentions of Balzac continue Miłosz's pre-war fascinations, which may have been intensified thanks to the writer's biography published in the United States. See Zweig, Stefan: Balzac. Translated by William and Dorothy Rose, Viking Press 1946.

277 After Judt, Tony: Postwar, op. cit., p. 254. 
and hence to the remnants of the New Deal. At the moment, all dams have broken, and the industry has free rein (...)." ${ }^{278}$ This policy model may, in his opinion, lead to economic meltdown. Reports for the Ministry of Foreign Affairs also contain skeptical comments about the limitation of competences and the ultimate elimination of the OAS. The memory of the crisis of the 1930s arouses his fear of making the market the only from of economic control. Knowing the model of state management of the economy, Miłosz considers the apparatus of power to be a necessary guardian of balance, hence in his mind an opposition arises between the principles of free market economics and social justice. Every so often, the newcomer from Europe foresees a crisis, a collapse of the market that is going to ruin those countries economically dependent on America:

America's economic moves are closely watched in the UK. Abolition of price control in the US when the rest of the world is starving, killing the U.N.R.R.A. and US opposition to the creation of an International Food Fund have been raising concerns in a large part of the Labour Party. At the same time, the following is being underscored:

(...) 2) That the US is sliding into depression, and linking the economy and politics of Great Britain with the economy and policy of the US may drag Britain into big trouble, because in the United States there are no people who would understand to what dangers the sort of economic policy that the United States has pursued after the first war may lead.

3) That, with the depression and fall in prices in the United States, English imports to the US will be prevented, while the American business will push the English away from foreign markets. These fears, therefore, seem to be more than justified. ${ }^{279}$

The fears, too, correspond with the attitudes of European builders of welfare states, who opposed post-war capitalism using post-war planned economy. As Tony Judt writes:

(...) planning was quite distinctly not associated with the discredited politics of the inter-war years, a point widely held in its favour. What planning was really about was faith in the state (...)

There was a great faith in the ability (and not just the duty) of government to solve largescale problems by mobilizing and directing people and resources to collectively useful ends. Obviously this way of seeing things was particularly attractive to socialists; but the idea that a well-planned economy meant a richer, fairer and better-regulated society was taken up by a very broad constituency, including the Christian Democratic parties then rising to prominence all over Western Europe. The English historian A. J. P. Taylor told BBC listeners in November 1945 that '[n]obody in Europe believes in the American way of life-that is, private enterprise; or,

278 Nowak, J. M. [Miłosz, Czesław]: Życie w USA, Odrodzenie 1946, issue 51-52, pp. 10-11.

279 Nowak J. [Miłosz, Czesław]: Życie w USA, Odrodzenie 1946, issue 51-52, pp. 10-11. The fears Miłosz expressed were related to Britain's attempts to secure a loan in the amount of USD 3.75 billion that were covered by the press. The US Congress granted the loan in 1947 in view of the necessity to protect Greece and Turkey from Soviet influence. 
rather, those who believe in it are a defeated party which seems to have no more future than the Jacobites in England after 1688. ${ }^{280}$

In the later installments of the series, Miłosz will combine political and economic forecasts, saying that "only in the analysis of economic phenomena can one look for data to predict the future."281 America in the first descriptions takes the form of a consummate player, who will leave even its traditional allies without any help in order to protect its own interests - these fears were shared by the British, who tried to keep US troops in Europe as long as possible. In a similar vein, Miłosz speaks about the United States's accession to the war. He believes that due to isolationism:

The United States did not enter the League of Nations, thus condemning it in advance to failure, and while Europe bred in itself ominous fascist dictatorships, the United States was indulging in illusions of peace. When Europe was bleeding in the Second World War, the fiercest supporters of leaving a free hand to the Germans emerged from the womb of the Republican party. These people fought against Roosevelt both for the New Deal and for leading the United States to participate in the war. What the results of the Republican victory will be, only time will tell, but it can be concluded that there are two kinds of isolation: open and covert, and that it is a delusion to believe that the demonic power of the United States can be used for purposes other than the most direct defense of its own possessions and interests. ${ }^{282}$

One would be hard-pressed to sound more critical. It shows not only deep Eurocentrism, but also regret about the situation of Poland, which resulted in some Polish-Americans casting their votes for the Republican Party.

Miłosz also educates his readers on the ABC's of local politics and economy. He proposes a sort of behaviorism: in the center of his analysis are the observable behaviors of groups and individuals. The measure of their importance is the reaction they receive. Thus, the author eagerly reaches for statistics, surveys, and measurable forms of description. The education proceeds quickly: in the first installment, the vocabulary from the handy Marxist dictionary is dominant, but later Miłosz tends to make use of American concepts. ${ }^{283}$ Despite numerous reservations, he declares his sympathy for the Democrats for their attitude toward participation in the war and their relations with the left:

The Democratic Party is also an old party, but its history abounds in splits, mainly boiling down to differences between the Southern and Northern Democrats. These splits had already become apparent during the Civil War, and the present moment has given them a new political focus. To

280 Judt, Tony: Postwar, op. cit., p. 90.

281 Nowak, J. M. [Miłosz, Czesław]: Życie w USA, Odrodzenie 1947, issue 8, p. 3.

282 Nowak, J. M. [Miłosz, Czesław]: Życie w USA, Odrodzenie 1946, issue 51-52, p. 10. Miłosz was familiar with the internal criticism of US isolationism in the realities of the Second World War.

283 In the reports, Miłosz uses the notions of the "left" and "right," which he does not do in the article series. 
say that the Republican Party is reactionary and the Democratic Party is progressive would be somewhat inaccurate, because in many Southern states there is only one list that traditionally goes to the elections - the Democratic one, and often very conservative-minded candidates are elected from it. ${ }^{284}$

The heterogeneity of the Democratic Party's character was particularly pronounced in the last pre-election campaign. The lack of a convincing leader, such as Roosevelt, led to the formation of two groups: moderate Democrats and radical wings with Wallace, Pepper and the CIO Political Action Committee. As a result, neither the moderate nor the radical voters on whose votes the party could count were convinced, and the danger was that many of them would listlessly stay at home on Election Day. (...)

The Democratic Party enjoyed greatest successes during the New Deal; its contribution was also the participation of the United States in the war. ${ }^{285}$

Miłosz also describes the political environment that does not fit very well to the two-party system. He makes the American left the object of his interest, both as a correspondent and sympathizer. He discusses the activities aimed at establishing the Progressive Party on the foundations of trade unions and the most radical factions of the Democrats. ${ }^{286}$ From this account, however, there emerges a superficial image of the leftist world - its true diversification is hard to grasp solely on the basis of very diverse attitudes to Soviet Russia. It would be far more interesting to capture the tensions resulting from the various degrees of internalization and understanding of communism. It is not enough to stress, however, that the correspondent was interested in presenting the atmosphere of American public life, signaling its most distinct phenomena. Neither the character of the series, nor the pace of observation, nor his intentions allowed more serious reflection on the complications of the political scene across the Atlantic.

\section{Around the Foreign Policy of President Truman}

Miłosz's first visit to the US took place during the presidency of Harry S. Truman. His order to drop the atom bomb is commemorated in the funeral poem "Trzy chóry z nienapisanego dramatu Hiroszima" [Three Choruses from the Unwritten Drama Hiroshima $]^{287}$ In 1945, the United States had a monopoly on nuclear weapons, which had not yet changed their relations with the USSR. Truman continued Roosevelt's policy: against Churchill's advice, he ordered the withdrawal of Anglo-American

284 Nowak, J. M. [Miłosz, Czesław]: Życie w USA, Odrodzenie 1946, issue 51-52, p. 10.

285 Nowak, J. M. [Miłosz, Czesław]: Życie w USA, Odrodzenie 1946, issue 51-52, p. 10.

286 On this, see Westerfield, Holt Bradford: Foreign Policy and Party Politics: Pearl Harbor to Korea, New Haven: Yale University Press, 1955, pp. 311-316.

287 Miłosz was familiar with John Hersey’s book Hiroshima, Harmondsworth: Penguin Books 1946, and the discussions around it in politics. More on this in Chapter Five. 
troops from the zone of Germany previously reserved for the USSR. In June 1945, America recognized the Polish communist government, and in December also the governments of Bulgaria and Romania. It was only toward the Soviet intervention in Iran that Truman's foreign policy became more firm. Its new course became clearer in February 1946, after the visit of Winston Churchill, who, in the Fulton speech, ${ }^{288}$ used the term the iron curtain, ${ }^{289}$ and after Kennan sent his "Long Telegram” from Moscow, warning against a new confrontation. ${ }^{290} 1946$ is the last year when Truman's policy towards the USSR was unsteady. When Miłosz began writing his series, a new strategy was being developed in the American-Soviet relations. In the second installment, he tones down speculations about the possibility of another war breaking out:

\begin{abstract}
American correspondents from Poland report with a great deal of astonishment that a significant number of Poles anticipate the imminent outbreak of war between the United States and Russia. The correspondents attribute this mindset to a lack of information about international politics, and they blame the Polish press for it, which, in their opinion, tends to portray events in world politics in a biased manner and to exaggerate disputes between the great powers. ${ }^{291}$
\end{abstract}

Despite this, Miłosz deals with the issue of American military policy, anticipating both a revolution in this field and a global arms race. ${ }^{292}$ Nowhere, however, does he mention the progress of work on nuclear weapons, nor the USSR's rivalry with the US in this field, which he extensively covers in his diplomatic reports. He only emphasizes how rich the Americans have become, developing the armaments industry during the war. To illustrate America's wealth in 1946, he provides numerical indicators in various industrial sectors - in subsequent episodes, he also eagerly reaches for numbers in his descriptions. Mathematical description is meant to give the readers an idea of how the economic situation dictates political decisions. Anticipating that the United States will invest in armaments, the author reports on work on a "mysterious camera,

288 According to his biographer, Truman very deftly used the fact that the criticism in the US of the USSR's policy was voiced not by him, but by Prime Minister Churchill. In David Horowitz's opinion, the tone of Churchill's speech surprised the Kremlin and the Americans alike, and the president was later forced to explain himself before the nation for his alleged unfamiliarity with the main points of the Fulton speech. See Horowitz, David: The Free World Colossus. A Critique of American Foreign Policy in the Cold War, Hill\&Wang 1965, p. 64.

289 Miłosz does not use this term in the series. He used it once in the episode that he withdrew upon reflection, and in the article "Książki i pisma w Stanach Zjednoczonych" [Books and Journals in the United States] signed as Żagarysta. In contrast, his reports discuss the significance of the Fulton speech for the changing course of the US foreign policy.

290 See Judt, Tony: Postwar, op. cit., p. 108.

291 Nowak, J. M. [Miłosz, Czesław]: Życie w USA, Odrodzenie 1947, issue 1, p. 7.

292 Miłosz discusses the possibility of the outbreak of World War III in his Raport sytuacyjny o nastrojach na terenie działalności Konsulatu Generalnego w New Yorku za okres 1 IX - 30 IX 1946 [Situational Report on the Moods in the Area of Operations of the New York Consulate for the Period from Sept. 1 to Sept. 30, 1946]. AMSZ, DPI, c. 21, b. 87, f. 1182. 
with which one will soon be able to see from America what is happening on the streets of Warsaw or Shanghai." "293 Another, more far-sighted statement reads: "In this new period, the greatest value is brought by a weapon that is very delicate, but also most effective: the human brain." ${ }^{294}$ The correspondent reports the headhunting policy aimed at German scientists who, in return for citizenship, saved the United States millions of dollars and years of scientific research. He appreciates the new direction of immigration policy, which was aimed at attracting top researchers. ${ }^{295}$

Miłosz discusses the problems of the US Army in its zone of influence in Germany - for the first time comparing the Americans to the Romans. ${ }^{296}$ He uses the report by Senator George Meader, ${ }^{297}$ who visited Germany on behalf of the committee examining the national defense program. Although the Democrats tried to keep the report secret, it was leaked to the press and provoked a heated debate, which was important for Truman's plans regarding defense policy. When, upon demobilization, he created the modern Department of Defense for the unification of the armed forces and advocated universal military service, public opinion demanded "bringing the boys back home." Thus, the President's intentions failed - even though Miłosz had full knowledge of this subject, he only cited press reports on the demoralization of the Army in Germany. He discussed the failure of Truman's plans with regard to mobilization and military service in his reports for the Ministry of Foreign Affairs - he said in them that the United States was effective in denazifying its own zone, but it was failing on the part of the Soviet Union because - unlike Soviet functionaries - the Americans do not make use of former Nazis. ${ }^{298}$ The diplomat was aware of Stalin's plans for expansion in Germany and his determination to unite the state under Soviet influence, but this knowledge did not seep into the article. ${ }^{299}$ He supported the American policy of economic unification of Germany, which he does not mention there either.

293 Nowak, J. M. [Miłosz, Czesław]: Życie w USA, Odrodzenie 1947, issue 1, p. 7.

294 Ibidem.

295 Cf. Nagan, Seymour: “Top Secret: Nazis at Work,” The New Republic 1947, issue 6, pp. $24-26$.

296 Arnold J. Toynbee shared similar reflections in a series of lectures delivered in the USA in 1960, when he warned about making dangerous analogies between the American and Roman foreign policies. He collected them later in the book America and the World Revolution, London-New York: Oxford University Press, 1962.

297 This is Meader, George: Confidential Report to the Special Senate Committee Investigating the National Defense Program on the Preliminary Investigation of Military Government in the Occupied Areas of Europe, November 22, 1946.

298 The US strategy of denazification is discussed by Judt in Postwar, op. cit., pp. 74-75; he also covers many aspects of Soviet cooperation with the Nazis. Ibidem, pp. 79-81.

299 In later years, the press used this issue for propaganda purposes. In Nowa Kultura 1950, issue 28, p. 8 a satirical cartoon was published with the caption "The USA, England and France want to coopt German Fascists as the fourth partner of for their aggressive purposes.” 
Since 1947, the Truman administration had been working on a strategy for Europe, especially the USSR, called - after Walter Lippmann - a "cold war." ${ }^{300}$ Miłosz emphasizes this phrase:

In America, an opinion that left much to be desired was born, that Russia is a difficult partner and that Roosevelt's concessions to her have not succeeded. The Republican program, in which there was no room for Wallace-Byrnes-type discrepancies, seemed more consistent. It must be mentioned that the Republicans were happy to accept Wallace's speech against Byrnes. ${ }^{301}$

Very early on, Miłosz draws attention to Wallace, who first as vice-president and then as Secretary of Commerce failed to notice the danger in the relations between the US and the USSR - the first episode was even accompanied by a photo of the rival of the president in office. ${ }^{302}$ He reports on the attitude toward Soviet Russia in the circles of Progressive Citizens of America and the Union for Democratic Action, from which a progressive party could emerge:

The rather friendly attitude toward the Soviet Union of a significant number of progressives [supporters of the New Deal policy and Roosevelt's line - E. K.], including Wallace, gives their opponents arguments that are forceful, as they appeal to national passions. It should be mentioned that most of the press writes about Russia at least sarcastically, and that most of the books on the Soviet Union present it in unflattering terms, and that the soldiers returning from Europe and the Far East are animated by feelings that are hard to call love for the Soviets, and they become propagators of anti-Russian propaganda. Under these circumstances, accusations of pro-Soviet sympathies and of cooperation with American communists can derail even the most logical of arguments.

(...) the progressives themselves are not a homogeneous group. Among their ranks one may include people with different beliefs, held to varying degrees of extremism. There are two radical wings among them: one extremely pro-Soviet and one emphatically anti-Soviet, while the rest must maneuver, at times siding with one, at times with the other group. ${ }^{303}$

Miłosz draws attention to the career of the main political players once the "containment policy" ${ }^{304}$ option had prevailed in Truman's administration. Both Wallace ${ }^{305}$ and

300 See Gaddis, John Lewis: The United States and the Origins of the Cold War 1941-1947, New York: Columbia University Press, 1972; Miscamble, Wilson D. C.S.C.: From Roosevelt to Truman. Potsdam, Hiroshima, and the Cold War, New York: Cambridge University Press, 2007.

301 Nowak, J. M. [Miłosz, Czesław]: Życie w USA, Odrodzenie 1946, issue 51-52, p. 10.

302 A broader, more nuanced characterization of this figure, taking note of various complications in his activities, can be found in the diplomatic reports. Also very interesting are the poet's later comments about Wallace, Inne abecadto [Further ABC's], p. 206.

303 Nowak, J. M. [Miłosz, Czesław]: Życie w USA, Odrodzenie 1947, issue 5, p. 9.

304 In Horowitz's opinion the term "containment” was not the name of the strategy taken up by the Truman administration, but was coined by the press upon Byrnes's return from Moscow, just before his dismissal as Secretary of State. See idem: The Free World Colossus, op. cit., p. 61.

305 See Stone, Isidor Frank: “Wallace Won’t Quit - Unless Asked To,” P.M. 1946, September 16, p. 3; Donovan, Robert J.: Conflict and Crisis, op. cit., pp. 218-228. 
Secretary of State James Francis Byrnes, ${ }^{306}$ a supporter of influence in Europe, were dismissed, and the position of the latter was filled by General George C. Marshall. But when the events in Greece and Turkey in the spring of 1947 brought about the fiasco of the policy of “containment," Miłosz's correspondence focuses on issues of racism, misconceptions of Poles about America, or the work of Wells. ${ }^{307}$ It was not until April that the author returned to reporting on foreign policy, including the principles of "get tough on communists" and "get tough on Russia." ${ }^{308}$ In the President's speech, which includes an interpretation of his doctrine, he notes the echoes of the Fulton speech. He claims that this firm tone was meant to support Marshall visiting Moscow. ${ }^{309} \mathrm{He}$ mocks the famous action of removing communists from the government's ranks:

The government has begun a great hunt for communists, throwing them out of government positions, etc. It is a hunt for a witch who has one bad side in the eyes of an observer. It is possible that some witches are responsible for the fact that the cows are not giving milk, and they might go to a secluded mountain every Saturday, where they are welcomed by a beautiful and gloomy Satan who, having heard all the neighborhood gossip from their mouths, offers them certain pleasures. But how does one distinguish a witch from a non-witch? Only some of them have an imprint of the Devil's paw on the buttock. What remains is dunking, but one can have some doubts as to its scientific basis. The atmosphere is thick, at times hysterical and not too distant from the atmosphere twenty years ago, when Sacco and Vanzetti, accused of anarchism, were executed. (...) In any case, for now the government has convinced the public that in this area it can even act alone, without the help of the Republicans.

Truman's turnaround in foreign policy was greeted by Republican politicians with a grimace of rage. They felt robbed. Their program envisaged a policy based on strength; they

306 In his reports, Miłosz writes about the rivalry between Byrnes and Wallace. He also takes note of the significance of Byrnes's speech encouraging tightening the course of US policy toward the USSR. Discussing this issue, he refers to the analyses made by Anne O'Hare McCormick, the New York Times foreign correspondent. See Raport o nastrojach na terenie działalności Konsulatu Generalnego w New Yorku za czas 1 IX - 30 IX 1946 r. [Report on the Moods in the Area of Operations of the New York Consulate for the Period from Sept. 1 to Sept. 30, 1946] AMSZ, DPI, c. 21, b. 87, f. 1182. On the circumstances of Byrnes's dismissal, see Westerfield, Holt Bradford: Foreign Policy and Party Politics, op. cit., p. 206.

307 Miłosz begins to cover the developments in the policy of the "cold war" in more detail only in August 1947. The rivalry between the USA and the USSR he calls a conflict of "impermeable and monolithic blocs." See Raport o nastrojach na terenie działalności Konsulatu Generalnego w New Yorku za okres 1 VIII - 1 IX 1946. [Report on the Moods in the Area of Operations of the New York Consulate for the Period from Aug. 1 to Sept. 1, 1946] AMSZ, DPI, c. 21, b. 87, f. 1182.

308 In the report, Miłosz covers the foreign policy in the Balkans as an element in the strategy of stopping the USSR. He also summarizes here the articles, very relevant in his opinion written by Walter Lippman of the New York Herald Tribune and by Anne O'Hare McCormick on the policy of the USA in relation to Europe and the USSR. See Raport o nastrojach na terenie działalności Konsulatu Generalnego w New Yorku za okres 1 IX - 30 IX 1946r. [Report on the Moods in the Area of Operations of the New York Consulate for the Period from Sept. 1 to Sept. 30, 1946] AMSZ, c. 21, b. 87, f. 1182.

309 Cf. Westerfield, Holt Bradford: Foreign Policy and Party Politics, op. cit., pp. 220-223. 
considered it one of the best tricks of election propaganda. They ground their ax lovingly, and it suddenly found itself in the hands of someone else. ${ }^{310}$

Miłosz also notes the political significance of Truman's speech regarding Greece and Turkey. When the British ceased helping the Greeks to defeat the communist uprising, and in view of the threat to the sovereignty of the policies of Greece and Turkey on the part of the USSR, the president made the axis of his doctrine support to all "free people who are resisting attempted subjugation by armed minorities or by outside pressures." ${ }^{311}$ America was expecting that in view of its monopoly on nuclear weapons, the Soviets would undertake expansive activities in Europe to strengthen their influence in the Mediterranean - Greece was thus a test of defense capabilities. ${ }^{312}$

Thus, as Anne O'Hare McCormick commented, by implementing the Truman Doctrine, the Americans were dragged into a new kind of war. In May 1947, the United States Congress passed a law on military and financial assistance for Greece and Turkey. Relying on the press, the correspondent presented a calculation of this policy. He suggested a mismatch between the publicly expressed intentions of aid and the expected profits related to America's involvement in European affairs. To David Horowitz as well, a later critic of the Cold War strategy, American involvement in Greek affairs and the implementation of the Truman doctrine were forms of marginalizing the UN's role in international politics. Similarly, Miłosz assesses the decision of the British as an attempt to protect the shaky empire:

Turkey? Greece? No one in America has any illusions about the Greek government. From the local press you can find out about its exceptional ineptitude and a desperate economy (an interesting fact: at the end of the war, rich Greeks took away capital from their country in the amount of 50 million dollars; no one has illusions about Turkey, which almost found itself on Germany's side. The British Empire, however, is retreating, in a very planned manner, to its new positions: to Africa, which presents unlimited possibilities, to Australia, with its large experimental fields for

310 Nowak, J. M. [Miłosz, Czesław]: Życie w USA, Odrodzenie 1947, issue 19, p. 2. American historians assessed this phase of Truman's presidency with similar skepticism. Cf. Caute, David: The Great Fear. The Anti-Communist Purge under Truman and Eisenhower, New York: Simon and Schuster, 1979.

311 On this, see Westerfield, Holt Bradford: Foreign Policy and Party Politics, op. cit., pp. 221-224; Donovan, Robert J.: Conflict and Crisis, op. cit., pp. 251, 274-278 and 285.

312 Howard Jones comments on this as follows: "Failure to defend Greece, the White House believed, would demoralize other nations and force them either to accept communism or to buy peace by making concessions to totalitarianism. American strategy entailed not only displaying its military strength in Greece but also proving to other nations that it possessed the will to help. The United States had to demonstrate an endurance capable of convincing democracy's enemies that they could not win. In an article in The New York Times entitled "Greece Is a Test of Staying Power" McCormick declared that Greece provided a 'preview of the frontless, almost faceless, war of tomorrow - a war of Trojan horses pointing the way for machine guns. The battle-line is everywhere and nowhere,' for the Kremlin's central directive was 'rule or ruin'." In idem: A New Kind of War. America's Global Strategy and the Truman Doctrine in Greece, New York: Oxford University Press, 1989, pp. 4-5. The attitude of the USSR to Truman's doctrine is analyzed by Judt, Tony: Postwar, op. cit., p. 127. 
missiles, and someone has to take over the inheritance. A certain journalist, whose nationality your correspondent will not even try to identify (if someone is a French woman born in Odessa, an American citizen and a wife of an Indian from South Africa, this is indeed difficult) said about the English almost crying, "They will set us up." 313

This opinion coincides with later assessments made by historians. Howard Jones aside from the defense of the sovereignty of Greece and Turkey - points to the global goal of Truman's policy in the Balkans, stemming from the fears of the White House about the possibility of the USSR including Turkey in its defense system, taking control over Greece and then the Middle East, which would allow the Soviets to flank the West in the Mediterranean and secure access to oil in the Middle East. ${ }^{314}$

Miłosz does not cover the Truman Doctrine - in its simplified assessment. Rather than that, he uses bons mots, in effect discrediting it. ${ }^{315} \mathrm{He}$ characterizes the president and his career path:

It is already said that there are two doctrines of US foreign policy: the Monroe Doctrine and the Truman Doctrine, being an extension of the first to the size corresponding to the present strength of the United States. As someone joked, the first doctrine forbade Europeans to interfere in American affairs, the other forbids Europeans to interfere in European affairs. The owner of a men's clothing store in a provincial town will probably go down in history as his mother dreamed, believing that he would yet become a great man when he sold ties. There is a particular kind of pathos in this, plus the lesson that the spirit of history flows through whoever it wants, and the lesson that playing political poker is usually a game with the Invisible Demon. ${ }^{316}$

This assessment is a synthesis of statements from The New Republic, where Truman's shopkeeper's past and his origin ${ }^{317}$ were readily recalled. Even then, in politics and

313 Nowak, J. M. [Miłosz, Czesław]: Życie w USA, Odrodzenie 1947, issue 19, p. 2. A voice complementing Miłosz's comments on the civil war in Greece can be heard in the poem "Przypomnienie" [A Reminder]. His criticism resonates with the diagnoses put forward by Horowitz: "Then, in the last days of January 1947, the worst snowstorm since 1894 descended on Britain and paralyzed her. Within four months, it was demonstrated to the world that where once the seat of mighty empire had stood, only a gaping power vacuum remained, so financially ruined as to be incapable of supporting army or navy, the necessary instruments of her will. As a result, India, Burma, Palestine were cast loose from British rule (Palestine to United Nations administration); South Africa, Guatemala, Argentina, Iraq and Egypt challenged the shell of English power in one way or another without suffering reprisal." In Horowitz, David: The Free World Colossus, op. cit., p. 72.

314 See Jones, Howard: A New Kind of War, op. cit., p. 8.

315 On the Truman doctrine, see Macdonald, Dwight "Notes on the Truman Doctrine," politics 1947, issue 3, pp. 85-87; Macdonald, Dwight "USA v. USSR," politics 1948, issue 5, pp. 75-77; Freeland, Richard M.: "The Truman Doctrine and the Origins of McCarthyism." In Foreign Policy, Domestic Politics, and Internal Security 1946-1948, New York: Alfred A. Knopf, 1972.

316 Nowak, J. M. [Miłosz, Czesław]: Życie w USA, Odrodzenie 1947, issue 19, p. 2.

317 This is discussed in detail by McCullough, David: Truman, New York: Simon\&Schuster, 1992, pp. 145-151. 
history, Miłosz sees mainly the territory of a clash of dark forces. He summarizes this belief in his correspondence published in the 10th issue of Odrodzenie:

Political poker is governed by rules independent of the will of the players. The rules work together along with coincidence, so important in America. In a word, something like statistical probability, based on a series of cases. There is, however, someone who shuffles the cards invisibly. The outline of his face, which sometimes appears, we call the (post factum) the necessity of historical processes. $^{318}$

For counterbalance, Miłosz does not conceal his growing recognition of the tactics adopted by Truman, who in his presidential campaign in the space of several months managed to improve his poll ratings, mainly due to the co-opting of some of his opponents' program, and thanks to skillful cooperation with the opposition in Congress. ${ }^{319}$ He calls the former tie merchant "a man of a strong hands; a bold, determined, great man of a country intoxicated with its new power." ${ }^{320}$ Based on the example of cooperation between the Democratic and the Republican caucuses in Congress, he describes patterns of interaction between the powers in the United States. However, he does not make in-depth comments. He sums this up more interestingly in his letters:

Making divisions according to European models completely fails and every writer should take this into account, because they can be in for a nasty surprise. Folk traditions are incomparably stronger in America than in Europe, which has gone through centuries of feudalism. In Europe, the source of every symptom of the continuity of this tradition tends to be attributed to very specific political views of the authors, which in most cases is an error. There is the tradition of Lincoln, of Roosevelt, the Wallace movement, but let us realize that they cannot be translated into the language of Europe. Incidentally, this is also the source of America's misunderstanding of Europe and the inability of Americans to think in terms of the differences clearly outlined in Europe (Zaraz po wojnie, 499-500).

Although Miłosz presents Congress as a territory of constantly heated disputes, a place where deals are made, and games are played, his knowledge of how people model the apparatus of power seems limited, hence the impression that he describes government institutions from the inside. We see not so much the political scene in the process of its formation, but detached scenes of a performance in which the actors appear on stage, fight out their battles and disappear. We can observe the external

318 Nowak, J. M. [Miłosz, Czesław]: Życie w USA, Odrodzenie 1947, issue 10, p. 6.

319 In one of the reports, Miłosz gives an account of the forecasts of The New York Times concerning the primary elections, foretelling a defeat of the liberals suspected of communist sympathies, as well as conservatives and isolationists. See Raport sytuacyjny o nastrojach na terenie działalności Konsulatu w New Yorku za okres 1 VI - 15 VII 1946 r. [Situational Report on the Moods in the Area of Operations of the Consulate New York for the Period from June 1 to July 15, 1946] AMSZ, DPI, c. 21, b. 87, f. 1182.

320 Nowak, J. M. [Miłosz, Czesław]: Życie w USA, Odrodzenie 1947, issue 19, p. 2. 
features of American democracy, while its formation remains a secret process. This sort of reductionism was necessary because of the size of each installment, and understandable if one remembers the aims of the series.

Miłosz omits the plan of economic aid for Europe ${ }^{321}$ announced by Secretary of State George C. Marshall in June 1947. ${ }^{322}$ He does not mention its benefits for Europe. The series also contains no mention of Kennan's famous article "The Sources of Soviet Conduct" (1947) published in Foreign Affairs nor the polemics with him published in the well-known article series by Lippmann titled "The Cold War" from 1947 - the text by Kennan, elaborating on the report of his stay in the Soviet Union, became the basis of Truman's policy towards the USSR. If Miłosz mentions General Marshall at all in the series, it is only in the context of his mission in China. Citing press reports, although without providing any titles or names, he comments as follows:

By appointing Marshall as secretary of state, President Truman has strengthened his own position. First of all, he is a very popular person in the United States and enjoys the sympathy of all camps. Secondly, Marshall, whose mission in China was to be planned in advance as a prelude to entrusting him with a higher position (it is emphasized that he was unsuccessful through no fault of his own) refers to Truman with special respect, which was not always possible to say about Byrnes who (as is rumored) often did not deign to inform Truman about his moves. There is also a rumor that Byrnes's resignation in a strange way coincides with the moment of London cooling its relations with the United States, and with attempts at a rapprochement with Moscow.

Marshall's first moves seem to foretell a certain discrepancy between his intentions and the Republicans' intentions. The decision to withdraw American troops from China was not welcomed with enthusiasm by the Republicans, and friction between Marshall and Vandenberg can be predicted, as the anti-Republican press supposes. ${ }^{323}$

321 See the series of reports "Let’s Face It, Mr. Marshall," The New Republic 1947. issue 6, pp. 16-19; Walton, William: "Men Around Marshall," The New Republic 1947, issue 12, pp. 15-19; "Marshall CoAuthors Truman Doctrine,” P.M. 1947, April 22, p. 1; “Most of Eastern Europe Favoring Marshall Plan,” P.M. 1947, June, 26, p. 6; Kuh, Federick: "Save Europe Meet Opens To Decide: 1 World or 2?," P.M. 1947, June, 26, p. 6; Moler, Murray: “Marshall: Aid Europe or Lose It To Russia,” P.M. 1947, July, 13, p. 3. The Polish press wrote about it in a critical tone. See Kruczkowski, Andrzej: "Plan Marshalla w dawnych latach” [The Marshall Plan in the Old Days], Kuźnica 1947, issue 45, pp. 8-9 and issue 46, p. 4.

322 Representatives of the Polish emigration at meetings attended by diplomats clashed most often over the reasons for Poland's refusal to participate in the Marshall plan. See Raporty propagandowe [Sprawozdania (pótroczne) $z$ działalności informacyjnej i kulturalnej na terenie Stanów Zjednoczonych za I i II-gie pótrocze 1950r. - Koresp.].[Opracowata Ambasada R.P. w Waszyngtonie] 1950-1951 [[Propaganda Reports [(Semi-annual) Reports of the on the Informational and Cultural Activities in the United States for the first and second half of the year 1950] [Prepared by the Polish Embassy in Washington]. AMSZ, DPI, c. 21, b. 87, f. 1175. On the perturbations related to the development and implementation of the Marshall plan, see Westerfield, Holt Bradford: Foreign Policy and Party Politics, op. cit., pp. 274-296; Judt, Tony: Postwar, op. cit.,p p. 115-126.

323 Nowak, J. M. [Miłosz, Czesław]: Życie w USA, Odrodzenie 1947, issue 9, p. 4. The relevance of Miłosz's remarks is confirmed by Donovan, Robert J.: Conflict and Crisis, op. cit., pp. 150-151. 
In addition to the mention of Marshall's mission, Miłosz shows in a cursory manner - in comparison with the reports - Truman's policy in Southeast Asia after the defeat of Japan. ${ }^{324}$ The United States took a stand early in the conflict between the Nationalist government of Chiang Kai-shek and the Communists led by Mao Zedong. The president prolonged helping the government and tried to prevent the resumption of the Chinese Civil War. ${ }^{325}$ The correspondent reports on the relationship of, as he puts it, "progressive circles" to this policy:

American intellectual circles do not count themselves among Chiang-Kai-shek's friends. Books on China talk about him mostly critically, more favorably assessing his enemies, the Chinese Communists. Recently, the Chinese Interior Ministry in Shanghai banned the sale of the book Thunder out of China by two authors - Theodore H. White and Annalee Jacoby. ${ }^{326}$

In China, also the educated spheres (according to the European or American system) sympathize with the Communists openly or secretly, because a right-wing dictatorship seems hopeless to them. Your correspondent has had the opportunity to talk with a young Chinese journalist who spent the war under the Japanese occupation: "Chiang-Kai-shek was a legend for us. We lived his name and we cried with joy as his troops approached. However, when we tasted the wild banditry of his army and the corruption of its officials, flags, lanterns and tears of elation gave way to depression." She did not say much, but I could deduce that the heart of this journalist, working for the Kuomintang dailies, was on the other side.

Reportedly, the situation in the territory under Communist rule (currently 140 million people) is also far from delightful, but educated Chinese see there some central idea, which Chiang Kai-shek lacks - something that is also shown well in his book. ${ }^{327}$

American historians wrote later of corruption, demoralization and desertions in the army of the Nationalist government. In the events in Asia, Miłosz sees laws similar to those acting in Europe: "We live in the period of dismantling of wartime legends and the Chinese are not alone in having to take recourse in their critical mind, against their habits." ${ }^{328}$ However, he hedges against the suspicion of propagandizing:

324 Nowak, J. M. [Miłosz, Czesław]: Życie w USA, Odrodzenie 1947, issue 10, p. 6.

325 On this, see Fairbank, John King, Goldman, Merle: China. A New History. Second Enlarged Edition, The Belknapf Press of Harvard University Press, 2006, pp. 329-330; Cohen, Warren I.: America's Response to China. A History of Sino-American Relations, New York: Columbia University Press, 2000. 326 A review of this book penned by Lawrence R. Rosinger was published in The New Republic 1946, issue 20, pp. 666-667, while Agnes Smedley - The Nation 1946, issue 22, no page number.

327 Nowak, J. M. [Miłosz, Czesław]: Życie w USA, Odrodzenie 1947, issue 10, p. 6. In the report Miłosz formulates a not too distant position - he says that Americans are hoping for a peaceful resolution of the conflict. It is also close to the address of General Evans F. Carlson, who demanded a withdrawal of US troops from China, since the society supported the Communists. See Raport sytuacyjny o nastrojach na terenie działalności Konsulatu w New Yorku za okres 1 VIII - 1 IX 1946 r. [Situational Report on the Moods in the Area of Operations of the New York Consulate for the Period from Aug. 1 to Sept. 1, 1946] AMSZ, DPI, c. 21, b. 87, f. 1182.

328 Nowak, J. M. [Miłosz, Czesław]: Życie w USA, Odrodzenie 1947, issue 10, p. 6. 
If I were to be accused of being biased when speaking about China, I must note that I am simply repeating the sounds of the Chinese cause, as one can hear them in America, and refrain from commenting on supplying Chiang Kai-shek with weapons, and from describing American business in Shanghai. ${ }^{329}$

The correspondent does not trust the assurances of the United States that it is involved in China solely for the cause of liberty. Under the guise of ridding China of the Communists, he sees concern for their own zone of political and economic influence (i.e. limiting the USSR's influence in Southeast Asia under the RooseveltStalin agreements) as well as economic influence (his report for the Ministry of Foreign Affairs mentions the sale of surplus military equipment to China for the sum of 175 million dollars). ${ }^{330}$

President Truman's foreign policy is referenced only selectively in the series. ${ }^{331}$ More specifically, Miłosz discusses the president's internal policy, his cooperation with Congress, legislation and the election campaign. A recurring subject is the activity of trade unions and labor strikes and their importance for the economic policy.

\section{Around the Internal Policy of the Truman Administration}

Truman entered the Oval Office under the difficult conditions of shifting the economy to functioning in the realities of peace. In his 1945 program, he presented a project to introduce benefits for workers and farmers, to expand the welfare state and establish a permanent commission for workers' affairs. Before proceeding with its implementation, he had to deal with a wave of labor strikes and a boycott of price controls. Miłosz outlines the context of these events in order to report on the president's further decisions:

The administration, in the hands of Democrats, tried with great difficulty to carry out a program of returning (reconversion) of the economy to peacetime conditions, maintaining price controls through the Office of Price Administration (OPA). It had to fight the ever-growing pressure from industry, which - despising all forms of control - tried to oppose it by fair means or foul. Industry had a powerful weapon: not providing the goods that were under control to the market. A paradoxical situation arose, where a country of abundance ran out of clothes, butter, sugar and meat in the stores. Several months before the election, meat disappeared completely from the market and appeared only when Truman had to eat crow and cancel the control of meat prices. When there were no goods in the stores, the public blamed not the producers, but the Democratic administration. (...)

\footnotetext{
329 Ibidem.

330 See Raport sytuacyjny o nastrojach na terenie działalności Konsulatu w New Yorku za okres 1 VIII - 1 IX 1946 r. [Situational Report on the Moods in the Area of Operations of the New York Consulate for the Period from Aug. 1 to Sept. 1, 1946] AMSZ, DPI, c. 21, b. 87, f. 1182.

331 On this, see The Truman Presidency. Edited by Michael J. Lacey, Woodrow Wilson International Center for Scholars, Cambridge University Press, 1989.
} 
So strong was the pressure from industry that the OPA was similar to a player trying to bounce a dozen balls at once. Since the end of the war, the price curve has continued to rise. In this way, industry tried to prevent the loss of its income resulting from a significant increase in workers' wages during the war, and it reduced the real value of employee wages. The consequence of this was the struggle of workers' unions to maintain the workers' standard of living, as well as a wave of strikes, which were generally successful. Workers increased their earnings, but industry did not give up and prices rose. The public blamed the administration for the strikes, and it became a scapegoat. ${ }^{332}$

This is a synthesis of events from before the beginning of the series. In February 1946, after demobilization, ${ }^{333}$ Truman signed a new law, fearing a crisis, to maximize employment and production, and to try to link prices with earnings. It caused dissatisfaction, mainly among businessmen, protests in the form of shortages in supply and stoppages at work, followed by mass strikes. In July 1946, there was an increase in prices and wages and a relaxation of economic control.

Truman vetoed the law extending price controls and withdrew from economic interventionism. In October 1946, before the congressional elections, he also abolished control over the distribution of meat. The victory of the Republicans, as a result of which the president was forced to cooperate with the opposition Congress, was considered an opportunity to withdraw from state control of the economy and move to the model of free market capitalism. Although initially regarded as a proponent of liberalism and a proponent of the New Deal in the field of economics and social policy, Truman used the slogan "Fair Deal" to emphasize the need to protect the weakest. When Miłosz arrived in the United States, he witnessed both the release of the economy from the influence of the state and the reactions to this process.

Truman announced favorable tax reform for the public, increased spending on housing and prevention of price increases. The correspondent scrupulously notes moves to stabilize the relationship between the cost of living and the earnings of the lowest-paid Americans. He quotes a fragment of his own statement: "If prices and wages do not find themselves in the right proportion, and quickly enough, there is a danger that the customer will stop purchasing, orders for industry will decrease, production will slump and unemployment will be created." ${ }^{334} \mathrm{He}$ emphasizes that he is carrying out a clever information policy, disseminating in the media proposals for reforms beneficial for the majority of society that the opposition would like to reject. He praises the negotiating abilities of the president, who does not buckle under the pressure of Congress or entrepreneurs. He speaks with admiration about the "Fair Deal" policy, whereby Truman wanted to:

332 Nowak, J. M. [Miłosz, Czesław]: Życie w USA, Odrodzenie 1946, issue 51-52, p. 10.

333 See Donovan, Robert J.: Conflict and Crisis, op. cit., p. 128 and 136.

334 Nowak, J. M. [Miłosz, Czesław]: Życie w USA, Odrodzenie 1947, issue 9, p. 4. 
1) lower the prices; 2) increase the purchasing power of the labor masses by improving social security, health services, cheap housing, combat racial discrimination, etc.; 3) regarding antistrike legislation that the Republicans are preparing, he declared that he would only agree to issue a law against the most drastic categories of strikes (the so-called "jurisdictional strikes"). ${ }^{335}$

Miłosz particularly appreciates the success achieved in housing: prevention of rent increases and maintaining rents at a relatively low level, which permitted migration to cities and resulted in increased employment. In spite of the Truman administration's efforts to maintain a balance between the costs of living and wages, in the absence of state price controls, in early spring of 1947 economists noted a price increase, which caused public concern and social dissatisfaction.

Looking at the political scene, the author treats it as an experimental field, which can be studied using tools almost like those from a naturalist's toolkit. Discussing the strikes, the results of voting, and the activities of various pressure groups, he wonders how a given stimulus affects the functioning of the organism of state administration. This tendency is evident especially in his discussions of the trade union environment - the quickest reactions are the easiest to notice here. Miłosz is particularly interested in the activity of trade unions because of the influence they exert on employers and legislators, the participation of workers in public life and their involvement in trade union activities. Based on observation of the methods by which the unions forced entrepreneurs and politicians to make concessions, and these were above all persistent strikes, he formed a view of democracy, and the degree of empowerment and maturity of the local workers. Aware of the dependence of the pace of European reconstruction on supplies from the United States, he is curious how the games between the unions, the employers and Congress will affect the development of the Old Continent. Already in the first episode of the series, he characterizes the most important trade union organizations: the American Federation of Labor (AFL) and the Congress of Industrial Organizations (CIO). He points out that they are not only involved in the defense of workers' rights, but take a stand on matters of internal and international policy, mainly towards the Soviet Union.

They proved their strength at the beginning of Truman's presidency when, after a wave of miners' strikes initiated by John Lewis, they secured wage increases. Miłosz's accounts show that the trade union environment was the seedbed of American communism: while the AFL demanded a tightening of the policy towards the USSR, the ranks of the new splinter-group the CIO consisted of no less than twenty percent communists. Although it officially renounced communism, the CIO did support leftwing tendencies among Democrats - Wallace, to whom the poet devoted so much interest, sympathized with these circles. ${ }^{336}$ Interestingly - as Judt says - the American trade unions in turn were kind to the European left and:

335 Ibidem.

336 More details and more interesting interpretations of the struggles between the AFL and the CIO 
The AFL-CIO, the US intelligence services, and the State Department saw moderate, trade unionbased social democratic and labor parties as the best barrier to Communist advance in France and Belgium especially (in Italy, where the political configuration was different, they vested their hopes and the bulk of their funds in Christian Democracy). ${ }^{337}$

The author also describes John L. Lewis, who was the leader of the United Mine Workers of America, a mining association belonging to the American Federation of Labor. He carefully observes the leftist movement with which the trade union movement had close ties. Lewis, despite his Republican beliefs, was initially a close associate of Roosevelt and supported his candidacy in the elections. In the 1940s, he played a negative role, first trying to prevent the United States from joining the war and then encouraging strikes when production intensified due to the rearmament campaign. According to the correspondent, Lewis's call for strike action, along with the improvement of the workers' situation (wage increases, shortening of the workweek while maintaining wages at the same level) in the period before the election, was aimed at settling the scores with his opponents before the new Republican Congress began introducing laws hindering strike actions:

Lewis's goal is to deal with rivals in the workers' movement. The CIO does not like Lewis very much. He was one of the founders of the CIO, which then he left with a bang. Currently, United Mine Workers belong to the American Federation of Labor. Leading this strike, Lewis defends the CIO, which, whether it wants to or not, must support this great workers' strike out of decency. In this way, the leaders of the CIO, constantly accusing the American Federation of Labor of procrastination, are outbid. It must be added that the CIO and AFL are not humble, little associations. They unite millions of members and their influence on American life is not less than that of the influence of industry barons. ${ }^{338}$

In the wake of price increases and trade union claims in the spring of 1947, a wave of anti-union protests swept through the country, and the Republicans began working on a new law on trade unions. In the 6th issue of Odrodzenie, Miłosz covers the

can be found in the reports. Miłosz writes about the speech delivered by William Green, president of the AFL, containing warnings about communists. This resulted in two unions affiliated with the CIO going over to the anti-Russian AFL. He also talks about ostracism faced by sympathizers of socialism in labor union circles. He underscores that labor unions are more absorbed here with defending employee rights than with politics. The only exception in this regard would be the CIO, in which communists tried to play a certain role. Miłosz emphatically states that "[the role of] communists in the US is non-existent," the communists who do not know the realities of life in the USSR he calls "idyllic communists." He also notes that in the US fascists are put on a par with communists, and both groups are thought of in terms of a fifth column. See Raport sytuacyjny o nastrojach na terenie działalności Konsulatu w New Yorku za okres 1 VIII - 1 IX 1946 r. [Situational Report on the Moods in the Area of Operations of the New York Consulate for the Period from Aug. 1 to Sept. 1, 1946]. AMSZ, DPI, c. 21, b. 87, f. 1182.

337 Judt, Tony: Postwar, op. cit., p. 263.

338 Nowak, J. M. [Miłosz, Czesław]: Życie w USA, Odrodzenie 1947, issue 2, p. 10. 
discussion on draft laws restricting workers' rights, at the same time noting the very moderate position of the president, who wanted to minimize the restrictions imposed on workers. Truman believed that one of the achievements of the New Deal was implementing the principles of protection of employee rights and he believed that, with the help of existing legal provisions, it was possible to deal with unjustified strikes and overly politicized trade unionists. The most important point of the discussion was the so-called 'closed shop' - the principle that workers in the factory belong to one union and no outside workers can be employed there, while the employees must be remunerated in accordance with the rates agreed with the union. This idea met with the resistance of employers and subsequent states introduced their own laws prohibiting the use of 'closed shops' - Miłosz raises this issue in the 10th issue of Odrodzenie. Congress decided to tighten this law and extend it to the entire country. As we read in Miłosz, the Lewis-led strike as a result of the firm stance of the president ended in a loss, the imposition of a high fine on the union and the personal failure of the leader of the United Mine Workers. ${ }^{339}$ The correspondent repeats the opinion that after the fiasco of the miners' strike, "the Republicans have one more advantage in their attacks on the world of labor and, as presented in a certain caricature, Lewis's coal is giving momentum to the Republican locomotive." 340

In June 1947, despite the President's veto, ${ }^{341}$ the Republicans voted for the law remembered as the Taft-Hartley Labor Management Relations Act, commonly called the 'slave-labor bill.' It regulated the conduct of employers during a strike, banned the practice of 'closed shops,' introduced control over trade union assets, forbade unions from participating in political campaigns and financing them, created a requirement for union leaders to document that they were not communists, and gave the government a periodic right to ban strikes (for up to 80 days). Before it was announced, trade unions warned against the global acceptance of this law and the rise of communist sympathies, also in Europe and South America.

These threats did nothing to affect the shape of the Taft-Hartley Act nor the attitude of Congress. Miłosz is critical both of it and of the team of the president's advisors:

No one can guess that the danger approaching the serene rural pastimes and Old Robinson's taverns is coming not from the outside, not from the remnants of the New Deal or communists. This danger is coming from the inside, it has the sleazy smirk of Taft [i.e. the co-author of the act limiting the activities of trade unions - E.K.], Dewey's mustache, fat belly of the senators.

339 More on this is written by Donovan, Robert J.: Conflict and Crisis, op. cit., pp. 208-218 and 238-242. 340 Nowak, J. M. [Miłosz, Czesław]: Życie w USA, Odrodzenie 1947, issue 5, p. 9.

341 In Truman's biographer's assessment, his veto in this matter had only a political dimension and was intended to gain the sympathy of workers. Donovan believes the Taft-Hartley Act to be one of the best laws passed during his presidency, despite the wave of protests that is sparked in the union circles. See Donovan, Robert J.: Conflict and Crisis, op. cit., pp. 298-304. 
Enter Hoover, the one whose name has been mentioned so far with a curse, and today Hoover is already included among Truman's advisors - Hoover - the one who in times of great crisis assured that "prosperity is just around the corner," and who used to call the unemployed lazy people who were not willing to work. Just as now, when the prices were released once again they shot up over the past month like a missile. Taft has a simple recipe: "you should eat less." And those who are already eating less - what are they supposed to do?

How can a resident of a small provincial settlement, to whom Taft is appealing in the name of "good old Americanism," understand that workers' unions are right in declaring Taft to be enemy number one? ? $^{342}$

Commenting on the strikes, Miłosz unintentionally becomes part of the national trend of criticizing American capitalism. Paradoxically, however, he gives testimony to democracy in which strikes and the activities of free labor unions were simply possible. Whenever the journalist touches on the affairs of farmers and laborers, his leftist ethos becomes visible:

I wish well to the people with whom I sat at a table in this remote corner of America: the worker from Brooklyn named Jack Wróbel who, as a sailor, took part in the invasion of Anzio and whose wife we chose as "the queen of oaks" at some picnic. The shopkeeper from Brooklyn whose ancestors lived in Sicily. The pair of funny, witty underground railway drivers from Boston with their wives. Old Mr. Henry, who never left his hometown and the surrounding area. The employee of a great New York store and her brother, who came back from the war a bit stricken. I wish them well and I see the dangers threatening them. Nowhere else have I realized so clearly how powerful is the inertia of a quiet province, over which politicians pursue their deals, leaving an illusion, but only an illusion, of their impact on the course of events. ${ }^{343}$

The member of intelligentsia of Wilno quickly finds out that the American worker sometimes speaks quite loudly about his affairs. His claims result from a sense of purchasing power, which has no relation to the aspirations of a Polish worker. Since the rate of economic growth depends on the level of consumption, the mass of buyers should be handled with skill. The correspondent draws attention to this already in February 1947, when the president tried to implement the provisions of the Fair Deal at the lowest possible social cost:

Presenting a budget of $\$ 37,300,000,000$, which introduces significant reductions in spending (with the exception of military spending and funds for veterans), Truman was in favor of maintaining taxes at the current level. As you know, he is an advocate of lowering taxes for those who have low incomes. In this way, the purchasing power of the wide masses would increase, which would be an important factor between supply and demand. (...)

Truman appealed to industry to maintain, or rather lower prices, and to workers for moderation in their demands for wage increases. The current state of the American economy is excellent. National production, amounting in 1946 to the sum of 205 billion dollars, is 50

342 Nowak, J. M. [Miłosz, Czesław]: Życie w USA, Odrodzenie 1947, issue 46, p. 4.

343 Nowak, J. M. [Miłosz, Czesław]: Życie w USA, Odrodzenie 1947, issue 46, p. 4. 
percent higher than pre-war records, and the rate of employment is at a maximum. The point is maintaining this situation. In 1946, due to the price increases, the purchasing power of the workers' masses decreased significantly. The most logical route, recommended by labor unions, would be to increase earnings and control the prices of industrial products. ${ }^{344}$

The condition of the economy becomes a key issue the closer a presidential campaign approaches. Miłosz notes that it begins long before the actual campaign of winning votes and that the main topic of discussion is the manner in which the candidate intends to maintain the rate of economic growth and secure the financial interests of citizens. In the spring of 1947 , he estimates that support for the Republicans is diminishing precisely because the public blames Congress for the sudden increase in the prices. The correspondent is involved in the observation of measures aimed at winning over voters. In April 1947, he comments:

President Truman is similar to a tightrope walker on a slippery rope. He wants to please this and that one. He forgot that he would fight overly restrictive anti-strike laws, but he is flirting with the other side as well, making concessions to manufacturers. He now has no weapon to fight the danger of depression. Several days ago he appealed to big industry for a voluntary reduction in prices, warning that if this does not happen, the demands of the workers' unions will need to be accepted. He also announced that in the event of an agreement between large enterprises to reduce the prices by themselves, the anti-trust law prohibiting similar agreements regarding imposing prices to the free market would not be applied. ${ }^{345}$

Direct quotations of the president's statements were possible because the president used the media, including the newly-developing television, to communicate with the public. Historians have drawn attention to his ability to shape public opinion, which gave him an advantage over the opposition and rivals in the election campaign, and that he strengthened in America the tradition of the president communicating with the nation. The correspondent mentions that the head of state was shown in newsreels before film screenings. ${ }^{346}$ As Truman was able to make statements which preempted his opponents' moves, in the spring of 1947 his ratings were higher than those of his rivals.

Miłosz does not take up various US domestic policy issues related to the aspirations to equality of various racial, ethnic and social groups. ${ }^{347} \mathrm{He}$ abandons

344 Nowak, J. M. [Miłosz, Czesław]: Życie w USA, Odrodzenie 1947, issue 9, p. 4. Cf.

345 Nowak, J. M. [Miłosz, Czesław]: Życie w USA, Odrodzenie 1947, issue 19, p. 2.

346 See Nowak, J. M. [Miłosz, Czesław]: Życie w USA, Odrodzenie 1947, issue 30, p. 5. In the report, Miłosz discusses reactions of the public to propaganda newsreels shown before film screenings - this would imply that the highest popularity at the time was enjoyed by the military and James Francis Byrnes, while the president's approval ratings were lower than those of Winston Churchill. See Raport sytuacyjny o nastrojach na terenie działalności Konsulatu w New Yorku za okres 1 IX - 30 IX 1946 r. [Situational Report on the Moods in the Area of Operations of the New York Consulate for the Period from Sept. 1 to Sept. 30, 1946] AMSZ, DPI, c. 21, b. 87, f. 1182.

347 See Borstemann, Thomas: "Jim Crow's Coming Out." In idem: The Cold War and The Color Line. American Race Relations in the Global Arena, Harvard University Press, 2001, pp. 45-84. 
discussions of politics in favor of other issues after about three months of sending in the episodes. Possibly the reason was his conviction, expressed in the 10th issue of Odrodzenie that "predictions in American politics are similar to the perfect roulette system," 348 or perhaps it was due to fatigue. Perhaps he wanted to finally separate the roles of the author of reports and correspondent. Certainly, he shifts his attention to the circle of politics, which provides him with a wider horizon of thinking. In the series, Miłosz presents the tip of the political iceberg in America. He seems to rely on other people's associations of facts and interpretations and assumes an equals sign between what exists and what others have observed. Therefore, after becoming independent (buying a car, more and more frequent trips to Reheboth, Boston, Detroit, Chicago, Vermont, Maine and Virginia), he found it more valuable to share other insights and observations.

\section{On the Agora of the Media and Publishing}

The American agora initially aroused negative reactions in Miłosz. As with many others, the United States reminded him of Rome, with Europe economically and politically dependent, but culturally superior - akin to what Greece was to Rome. He expressed these remarks mostly in his letters and poetry, particularly in "Przypomnienie" [A Reminder]. ${ }^{349}$ Incidentally, Wittlin wrote in a similar vein at the news of the Nazis bombarding Greece. ${ }^{350}$ Sometimes the thought of America as the fourth Rome refers to its policy of expansion. Sometimes, as in this case, the memory of Europe-Greece is the source of a critical, at times paternalistic attitude towards the United States. When anger and bitterness pass, the poet is forced to discover in the tumult of the agora the laws that govern it. Seeing the extent to which they are conditioned by economic factors, over time - though not without opposition - he begins to describe it as a market for an economic exchange of ideas. ${ }^{351}$

In this area, he uses a twofold method: as before, he collects information from the press, uses statistics and figures, but now he adds personal commentary to them

348 Nowak, J. M. [Miłosz, Czesław]: Życie w USA, Odrodzenie 1947, issue 19, p. 2.

349 It is possible that the source of "Przypomnienie" [A Reminder] may have been Miłosz's thorough reading of W.H. Auden's poetry, including his poem "September 1, 1939". Auden bemoans the fate of Europe, recalling the History of the Peloponnesian War by Tucydides, in which Pericles delivers a funeral oration on the eve of the fall of Athenian democracy.

350 See Wittlin, Józef: “Żałoba po Helladzie” [Mourning for Hellas]. In idem: Orfeusz w piekle XX wieku [Orpheus in the Underworld of the Twentieth Century]. Afterword by Jan Zieliński, Krakow, 2000, pp. 144-146.

351 He was not alone in taking this stance. Mieczysław Wionczek, the New York correspondent at the time wrote "O chorobie dziecięcia pieniądza" [On the Disease of the Child of Money], Kuźnica 1948, issue $13-14$, p. 10 and 18. 
more often. When describing publishing, the book market, media policy, information culture, and the cycles of fashions in popular culture, he feels more at ease, and he spreads his wings more as a correspondent. This is where his tendency to watch society in motion, which he so admired in Balzac, comes into its own.

Here, too, Miłosz separates the roles of the correspondent and the poet, publishing either under his own name or as Żagarysta. In the series, he writes about literature, cinema and new media, but entirely omits theater, music, art or photography. The roles of the correspondent and the diplomat are also separated. The most evident manifestation of this practice is his report from the Polish book exhibition in New York - the attaché reports on its preparation in his diplomatic reports. In the 25th issue of Odrodzenie there is no mention of it having been visited it by around 20,000 people nor its promotion in the editorial office of P.M. He sticks to the role of a visitor who enjoys the popularity of Polish literature in exile.

Miłosz's correspondence on culture takes into account the existence of many ways in which it circulates, touching on issues of popular culture as well. The texts are adapted to the needs of the national intelligentsia. In his literary essays, Miłosz presents analyses of high culture phenomena, while in the series he reveals the commercial mechanisms of middlebrow culture. He sometimes shifts from summary to commentary, as in the case of David Davidson's best-selling book The Steeper Cliff ${ }^{352}$ or William Wyler's film The Best Years of Our Lives. ${ }^{353}$ Mostly, he does not stop at mere reporting, but tries to reveal the rules of the cultural market.

He draws attention to the phenomenon of book sales ranking and analyzes the current best seller lists. ${ }^{354}$ He notes that the first places are taken by nonfiction books: analyses from the borderlands of political science and sociology (e.g. devoted to Roosevelt's politics), biographies, documentary prose, historical books and guidebooks. In his press recommendations Miłosz makes a selection which illustrates well his interests and beliefs. For example, he devotes an entire episode to Sternberg's book, The Coming Crisis, ${ }^{355}$ and omits political studies that, unlike it, have withstood the test of time. He does not mention Lippmann, who in his study titled "Cold War" engaged in a polemic with Kennan, and whose journalism in The New Herald Tribune Miłosz highly appreciated. He devotes a mere note to the important book Underground to Palestine by Isidor F. Stone, about the situation of Jewish refugees who attempted to cross the British blockade trying to get into Palestine. It was written on the basis of articles published in P.M., where Stone was one of the leading journalists. For this series P.M. was honored with prestigious awards, while Stone was considered to be

352 See Nowak, J. M. [Miłosz, Czesław]: Życie w USA, Odrodzenie 1947, issue 47, p. 3.

353 See Nowak, J. M. [Miłosz, Czesław]: Życie w USA, Odrodzenie 1947, issue 30, p. 5.

354 Various best seller lists were published by The New Republic, The Nation and Partisan Review.

355 See Sternberg, Fritz: The Coming Crisis. Translated by Edward Fitzgerald, London: Victor Gollancz Ltd., 1947. 
one of the authorities of investigative journalism - the author of the series does not boast of his acquaintance with this group, although he did write about exchanging contacts with them in his diplomatic reports.

Above all, Miłosz wants to give his readers an idea of how the book market worked in America. The poet is struck by its cosmopolitan diversity. The local bookstore appears to him - like the stock book in Sanatorium Under the Sign of the Hourglass - the world in miniature. The wealth of publishing in the USA awakens a pedagogical passion in him - he appeals to expand the Polish book market with foreign publications, not only the latest, which require the acquisition of costly copyrights, but the classics that have not yet had good translations. Among Englishlanguage authors he recommends Swift, Dickens, Defoe, Jane Austin, George Eliot and Henry Fielding. He argues that post-war moral changes allow bolder translations of texts that have thus far either been censored, bowdlerized or omitted. He sees the greatest backlog in translations of Shakespeare.

In February 1947, Miłosz devotes the entire installment to the dynamics of the publishing market. He discovers the other, economic side of the world of books: professional marketing, aimed at increasing sales, but also promoting readership. In his descriptions of the cultural machine, he wants to be as useful as possible: he smuggles ideas and suggests proposals to be transplanted to Poland. He covers the principles of operation of the "portable library," referring to the Portable Library series launched during the war by Viking Press. He appreciates the merits of the Penguin Books and the Modern Library series, and emphasizes the importance of subscriptions and book clubs in popularizing readership. The most interesting observation transcends the realities of publishing:

Incidentally, this lack of a center in particular fields is a novelty to foreigners coming [to] the States, with which they cannot get used to it for a long time. The threads do not converge anywhere, or at least you cannot trace them. Searching for the center here is the same as searching for the center of a forest. What would be simpler than, for example, an institution with which foreign booksellers and publishers could communicate? But even this the United States shook off, like a dog coming out of the water: there was apparently something in it of the atmosphere of Roosevelt's New Deal. ${ }^{356}$

It is not known whether this intuition was Miłosz's original insight or a remark he heard in the circle of politics. As we know, Daniel Bell will develop the issue of the absence of a center in America in much later work, The Cultural Contradictions of Capitalism. ${ }^{357}$ Even though the poet fails to find a center of the book market, he does identify other centers of American reality. As a newcomer from a small country, where

356 Nowak, J. M. [Miłosz, Czesław]: Życie w USA, Odrodzenie 1947, issue 10, p. 6.

357 See Bell, Daniel, The Cultural Contradictions of Capitalism, 1978, New York: Basic Books, and “The Coming Tragedy of American Labor,” politics 1944, March, pp. 37-42. 
artistic life was concentrated in several major cities, he seeks the authorities who set the tone of thinking and action for the lesser circles. Hence his observation of the market as a supposed center of events.

Miłosz quickly realizes that the cultural bond across the Atlantic exists not only in keeping with the center-and-periphery model. By repeating the idea that America is a province, he also has in mind the concepts of regionalism and locality that are defined and valued differently from the way they are seen in Europe. He utters the words about the absence of a center in the context of dissolution of the United States International Book Association (USIBA), whose aim had been to facilitate communication between publishers and exchange books with Europe.

Another installment is an analysis of the media market. Miłosz asks: "What does freedom of the press look like in the United States? This question is asked repeatedly, and usually two answers are given: there is no freedom of the press in the United States; there is absolute freedom of the press." ${ }^{358}$ The basis of his analysis is A free and responsible press - a report prepared between 1943 and 1947 by an independent expert committee affiliated at the University of Chicago. ${ }^{359}$ The author draws from it the most important information which, fresh as it may have sounded in Poland in the 1940s, from today's perspective seems to be a testimony to the very typical transformations of the media under the influence of technological progress, concentration of capital, monopolization of the press market and the infosphere. Miłosz treats these phenomena as restrictions on freedom. Predating Marshall McLuhan's remarks somewhat, he points out that the medium is itself the message. ${ }^{360}$ When more and more people choose the radio and television as a source of knowledge instead of the press, the maintenance costs of the latter increase. A remedial measure is consolidation, which leads to the formation of corporations and unification of information. Following the experts, the author lists how many periodicals disappeared between 1909 and the 1940s, without mentioning the circumstances of the Great Depression or wars. He connects their downfall with the monopolization of the market. He also touches on the sources of information themselves:

Only part of the material published in the press is penned by editorial teams. The provincial press receives ready editorials, illustrations, stories, etc. from special press syndicates and agencies. $95 \%$ of daily newspapers use the services of one of the three news agencies: International News Service (controlled by Hearst), United Press (controlled by the Scripps-Howards chain), and Associated Press (owned by a group of publishers).

358 Nowak, J. M. [Miłosz, Czesław]: Życie w USA, Odrodzenie 1947, issue 21, p. 5.

359 This is the edition of the Commission on Freedom of the Press, A Free and Responsible Press, Chicago: The University of Chicago Press, 1947. An extensive analysis of this report was presented by Reed, William K., Jr.: “Free Press in a Free World,” The Nation 1946, issue 23, pp. 684-686.

360 McLuhan was a reader of politics - in the issue of September 1946, p. 279 he took part in a discussion on feminism and coeducation. 
Photographs, editorials, and so-called "comics" are sent to the papers by about 170 syndicates competing with one another. The largest (and therefore able to provide the desired material cheapest) are the owned by corporations which possess both a large number of papers as well as the agencies. ${ }^{361}$

Miłosz draws attention to a similar situation with the radio. He is irritated by the interruption of radio and television broadcasts by commercials, and too many paid advertisements in newspapers.

Miłosz neither defines nor poses the problem of the concept of freedom. If he claims that freedom of the press in the United States is threatened, he may refer to a threefold situation: violation of the freedom of work of individual journalists and the autonomy of editorial teams, the use of coercion, such as controlling or regulating the means of obtaining and disseminating information, establishing and running newspapers, radio and television stations, and exerting pressure on the distribution of information: depriving people of their freedom of expression, or access to news from a variety of sources.

Restrictions on freedom of the media are traditionally connected with the operation of the power apparatus, the use of preventive censorship, licensing of the press, etc. There is no mention of such phenomena here. In turn, concentration and commercialization of the media are in turn inevitable processes in the modern economy, and they were easiest to observe in the United States, where the media industry was developing most dynamically. On the other hand, the correspondent does not address the issue of racial segregation, a significant problem of radio and television - in the 1940s, non-white employees had no influence on the choice and form of information, educational and entertainment programs. The supposed recipient of these media was a white American, and this perspective did not arouse reflection in the European at the time. The media are discussed more comprehensively and more interestingly in the article "Książki i pisma w Stanach Zjednoczonych" [Books and Journals in the United States]:

At the outset, let us state that the United States is a land of a huge publishing movement. Let us also state that any analogies with the European continent fail, and that, as in other areas of American life, judging on the basis of a comparison is a path leading to error. Let us try to draw the most cursory map of the phenomena, starting with magazines. For this purpose, would the reader please follow me, for example, to the corner of Broadway and 72nd Street. Here, at the subway station we find are large newsstands, not the largest in New York, merely average in capacity. At the beginning, of course, we will come across enormous piles of newspapers and The New York Times, containing as much paper as a book of several hundred pages - a newspaper that is esteemed, and considered by many of its readers, to be the best and best-informed journal in the world. Next to it is the New York Herald Tribune, its rival. Having purchased one, I check it to see if it contains an article by Walter Lippmann on foreign policy today. On Sunday, if I buy these two papers, I bend under their combined weight: The New York Times has a literary

361 Nowak, J. M. [Miłosz, Czesław]: Życie w USA, Odrodzenie 1947, issue 21, p. 5. 
supplement The New York Times Book Review, another supplement devoted to photographs and longer articles: The New York Times Magazine, an overview of political events of the past week, a financial review, a sports review, and an overview of film and theater, and performance arts. Similar supplements, slightly slimmer, are offered with the New York Herald Tribune. Of course, advertisements occupy the majority of the space in these magazines. It is not me, a passer-by who gets this stack of recycled paper almost for free, that pays for the army of writers, correspondents, printers, and distributors whose work contributes to the making of a newspaper. The advertisers pay for it. Ads did not use to appear in P.M. notices, a small-format journal, ideological and representing the policy of the left wing of the Democratic Party and the Political Action Committee of the CIO, but it has also succumbed to the trend and to economics. These three papers satisfy my thirst for information. This is also true of several hundred thousand New Yorkers. The New York Post has its regular readers, the communist paper Daily Worker also has some, but millions of residents of Manhattan, the Bronx, Brooklyn, and Queens prefer different reading matter - the Daily Mirror. ${ }^{362}$

In the further stages of the walk, Miłosz discusses the popular press and weekly magazines - among them Time, Newsweek and political weeklies: The New Republic, The Nation, The Protestant and New Masses. He does not forget weekly magazines and specialist monthly magazines, including the Saturday Review of Literature. He concludes with a discussion of the literary magazines:

This is the geography of papers that can be bought on the street. There is something missing here, is there not? I know what: probably the literary weeklies, such as the Nouvelles Litteraires, our pre-war Wiadomości Literackie or Odrodzenie, or literary notebooks that Paris is covered with. Tough, they are not here and that's that. Yes, there does exist something similar. But these are high places where it is difficult to breathe and I am afraid that the conditions there are similar to boredom. If we go to the 42nd street, by the Public Library building, we will get the bimonthly Partisan Review in the kiosks there, English in its language, French in its spirit and, as usual for such hybrids, raising certain doubts, although they do publish the best English, French, American names. There, we will also get Art News and Theater News, very conventional papers at that. One more step, and we are already in the land of specialists, among a multitude of professional journals from various fields, issued by universities, or among "reviews" which have their subscribers and appear in public only in the reading rooms of libraries. Such critical literary journals as Kenyon Review, Sewanee Review, Yale Review are not to be had at the newsstand - no willing buyers. ${ }^{363}$

Miłosz shows considerable orientation in matters related to circulation of information in the United States, although he passes over many issues, such as the level of given title or rivalries between various papers (in the 1940s in New York, the Times was competing with the Herald Tribune, the liberal Post and the somewhat less sophisticated World Telegram). Nor does he discuss the racial and ethnic diversity

362 Miłosz, Czesław: "Książki i pisma w Stanach Zjednoczonych" [Books and Journals in the United States], op. cit., p. 1.

363 Ibidem, p. 2. 
of the media market (represented even by the African-American Pittsburgh Courier, Negro Digest and The Chicago Defender) or the dynamically developing sector of the women's press, in which the leftist Ladies Home Journal played a vital role. Miłosz also does not mention the other processes that shaped the information market. Marek Gołębiowski comments on this as follows:

\begin{abstract}
Complicated were the relations of the press and television, as the latter, taking over a lion's share of nationwide advertising, undercut the basis of existence of the former voluminous magazines. Instead, their more expensive, and thinner counterparts appeared, usually as monthlies, as did the weekly information magazines Time, Newsweek and U.S. News and World Report. In addition to revenue from advertising, television also deprived the press of the time that the audience had previously spent on reading. Soon, the publishers realized that it was no longer possible to beat TV in the field of absorbing the viewer's entire attention - and so they began to focus on informing the reader in a way that was unavailable to television, because the newspaper is a physical medium that can be returned to at any moment, regardless of the programming schedule. The local character of newspapers allowed them to focus on the interests of the community; in addition, they could provide information that only a few readers were interested in, without boring all the others. Newspapers focused more on giving details of events and their deeper context, obtaining material that was uninteresting to television, which, for instance, never waged any crusade. ${ }^{364}$
\end{abstract}

This episode in the series foreshadows Miłosz's reflection on mass culture, ${ }^{365}$ and at the same time a culmination of the thread woven in since the beginning of the series, when the author complained about the how anodyne radio and television programs and the cinema were, and how tawdry popular entertainment was in general. ${ }^{366}$ Here, he rather provides an insight into the economic mechanisms shaping the local information culture. However, what emerges from the article is an incomplete picture. The reader may get the impression that the world of mass media is ruled only by impersonal institutions against which mere individuals are powerless. In the light of the series, if one wanted to answer the question which was the motor of change - individuals or institutions, a strong personality or its environment, one would need to reply that incorporeal beings ruled here, eliminating each other in an almost Darwinian manner, and establishing their successive laws. The history of the press from the period preceding Miłosz's stay in the United States saw charismatic journalists who introduced new working principles, and new rules for acquiring and presenting material - figures such as Joseph Pulitzer or Ida M. Tarbell in the area

364 Gołębiowski, Marek: Kultura Stanów Zjednoczonych, [Culture of the United States] Warsaw, 2006, pp. 437-438.

365 Nowak, J. M. [Miłosz, Czesław]: Życie w USA, Odrodzenie 1947, issue 21, p. 5. Miłosz already knew Dwight Macdonald's essay, "A Theory of Popular Culture”, politics February, 1944, pp. 20-23, that was included in the anthology Mass Culture. Judt mentions a similar aversion to American popular culture in left-leaning European emigré circles, Postwar, op. cit., pp. 265-266.

366 See Nowak, J. M. [Miłosz, Czesław]: Życie w USA, Odrodzenie 1947, issue 1, 7, 31, 43. 
of investigative journalism. What brought on the words of the article? Perhaps Józef Wittlin shows it best:

\begin{abstract}
We usually expect more of America than of our own selves. In recent decades, a large part of the European population has lived in such unhealthy conditions that America seemed to be the highest moral arbiter on the planet. To European enthusiasts of the fiction that is called justice on Earth, the symbols of this justice were often presidents of the United States. Whenever anything bad happened on the old continent, when oppression gained the sanction of law, many victims turned to the Statue of Liberty on Bedloe Island and said, "What will America say to this?" America was also the distant higher instance, under whose gaze the people responsible for the conscience of their societies felt ashamed. (...) And that is why everything that leaves something to be desired in this country strikes us with far greater strength than in Europe, where pessimism was often a valid philosophy of life, and disbelief a foundation of faith. ${ }^{367}$
\end{abstract}

Miłosz also draws attention to the phenomenon of hegemony described by theorists of popular culture in politics. He becomes familiar with the methods of the local propaganda, which will allow him to build parallels between manipulation strategies in the US and in the USSR. One of the forms of building, as Leszek Kołakowski would say, the culture of analgesics, is to popularize here a fairy-tale version of reality:

Going deeper into dreamland, a land of dream and fantasy, shedding tears over the fate of heroes in the company of an audience consisting of saleswomen from large stores (the painted and polished lowest proletariat in America), stepping out of the cinema with the stagger of drunks or people who had been taking drugs for 3 hours is an almost charming activity. Yes, American cinema is a 'factory of dreams.' These are, however, let us admit it, generally poor dreams, where elements of known everyday reality are endlessly reshuffled. (...) There is an interesting story related to all this pretense. The partner with whom Joe had been running the gas station - he turns out to be millionaire in disguise. Then the girl suddenly discovers talent and becomes a great actress. Then again a friend unexpectedly makes a big career and kidnaps a whole bunch of his Brooklyn buddies into a world of indescribable joy. One of the basics of America is the myth of Cinderella, of a sudden happy resolution. ${ }^{368}$

The author soberly evaluates these practices and sheds light on their European, folk pedigree:

A drug. Yes, but let us think for a moment. Humanity has been using large doses of fairy tales for many thousands of years. The only thing that changes is the center of power. In Greece, you met a foreigner on the road, you offered wine, and later he turned out to be one of the gods. In folk tales an old beggar, clothed and fed, was sometimes God the Father himself, or a saint. In Shakespearean theater the same role was played by a disguised king or prince. It has already been pointed out that Balzac's Paris had all the features of a city from a fairy tale: a meeting of

367 Wittlin, Józef: "Mój pierwszy rok w Ameryce” [My First Year in America]. In idem: Orfeusz w piekle XX wieku [Orpheus in the Underworld of the Twentieth Century], op. cit., p. 317.

368 Nowak, J. M. [Miłosz, Czesław]: Życie w USA, Odrodzenie 1947, issue 30, p. 5. 
the right person at the right moment took on the power of a magical spell there; from the very bottom it would lift one straight to the top. ${ }^{369}$

For Miłosz, popular culture is located inside the American cinema. As a resident of the East Coast, he does not record the development of jazz, swing, bebop, blue grass or the musical, including the black musical. He does not follow the careers of Duke Ellington, Louis Armstrong, Benny Goodman, Glenn Miller, Charlie Parker, Thelonius Monk, Ella Fitzgerald or Billie Holiday; in New York he is not attracted by the growing international fame of Leonard Bernstein.

Regarding censorship in the cinema, he emphasizes that popular culture is sometimes a form of creating behavioral patterns in contrast to European propaganda. He does not, however, touch on the absorbing subject of the House Un-American Activities Committee, which initiated proceedings against communist influences in Hollywood, or the effects of the Paramount Decree. He seeks to explain the paradox of society shaping people to be inventors, and at the same time preserving their state of mental lethargy. He is tired of the conviction held by Americans of their own superiority when evaluating the international situation. He shows this in his reports: he is struck by the insignificant role played by intellectuals in public life, and by how weakly their activity reverberates in society. ${ }^{370}$ Moving in New York's intellectual circles, Miłosz observes many-sided isolation within the local educational system, whereby any circulation of ideas is limited in scope. In Życie w USA, he praises the American school, which uses the latest achievements of psychology, but then observes how the ability of critical thinking is suppressed in confrontation with the taboo, compliance with which is a prerequisite for being part of the elites. In the report of the conference at Bread Loaf, he describes this process as "sterilization," ${ }^{371}$ in other places he expresses the notion of sterility of American academia.

\section{On Several Anticipations}

In four installments, Miłosz moves away from reporting the phenomena of publishing and changes in the world of media in favor of comments that occupy a more prominent place in his intellectual biography. Two installments are indirectly devoted to Wells and Mann, and reveal one of his most important questions.

369 Nowak, J. M. [Miłosz, Czesław]: Życie w USA, Odrodzenie 1947, issue 30, p. 5.

370 Cf. Wright Mills, Ch.: "The Powerless People. The Role of the Intellectual in Society," politics 1944, April, pp. 68-72.

371 Miłosz, Czesław: Raport z pobytu na Konferencji Pisarzy w Bread Loaf, Vermont w czasie od 13.VIII do 28.VIII.1947. [A Report from the Stay at the Writers' Conference in Bread Loaf, Vermont, from Aug. 13, to Aug. 28, 1947] AMSZ, c. 221, b. 89, f. 1171, p. 2. 
In the installment on Wells, from March $1947,,^{372}$ a pretext for reflection is the posthumously published book Mind at the End of its Tether, ${ }^{373}$ which is a sort of testament and assessment of life. By introducing the reader to the sphere of its issues, with sympathy toward Wells, Miłosz touched on issues that had been bothering him since childhood. The center of his attention was occupied by the relationship between reason, seeking liberation from the influence of culture and religion, and the experiences of life, which reason, or consciousness, cannot remedy or handle. Miłosz's Wells is someone who absorbed the ideas of the era, and then drew his own conclusions from them, trying to project its achievements as far as possible into the future. A disciple of Darwin, an unwavering evolutionist, a proponent of scientific cognition who rejects metaphysics remained powerless in the face of history, as did those who did not follow reason as far as he did. Miłosz argued here that no matter how much the war discredited the path of progress and pure reason, Wells would have remained a sardonic pessimist in any case. The poet read Wells through the prism of Shakespeare, showing the continuity of a certain logic of capturing reality, which, although based on variable foundations, was built in England over several centuries. The object of his partial reflection is pessimism, as an intellectual attitude, in conjunction with the heroism of taking action, which combination of features was close to him throughout the entire decade.

Wells's philosophy summarized in the booklet in question is Miłosz's vehicle for returning to the Darwinism and scientism of his Gymnasium days. The experience of war makes him face the necessity of a renewed confrontation with this worldview, and raises the question of whether or not Wells' death marked the end of his era. Miłosz sees similarly the extent of defeat of the liberated reason in the individual and social dimension, posing questions in the intellectual climate of Freud and Einstein. However, some shifts of emphasis are notable here. Deprived of his illusions, Wells leaves with the reflection:

In an anthill there are immense and undecided masses, whose leaders, incapable of realizing what is happening, resort to the worst and most harmful magic spells to reverse the desperate fate looming over us all. An accusation that mixes past superstitions with new cruelty is thriving. The unfortunate ant, tangled in these moving masses, tries to maintain his faith in those to whom he entrusted himself. Thus he will probably follow his path all the way to the end. He may feel uncertain and uncomfortable at times, but, as will his companions, he will usually maintain the atmosphere of heroic emptiness, convincing himself and others that now the old game will be started anew, and its current downsides will dissipate like a dream. And before he becomes conscious enough to relate the dream of his renewed world, he will forget all about it and enter nothingness forever. ${ }^{374}$

372 Nowak, J. M. [Miłosz, Czesław]: Życie w USA, Odrodzenie 1947, issue 11, p. 6.

373 Wells, H. G.:, Mind at the End of its Tether and the Happy Turning. A Dream of Life, New York: Didier, 1946.

374 Nowak, J. M. [Miłosz, Czesław]: Życie w USA, Odrodzenie 1947, issue 11, p. 6. 
These words caught the attention of the poet, who wrote poems about helpless clusters of human insects several years before. What could the hypothetical end of Wells' era mean to him? In the situation, diagnosed so accurately by Wells, of the powerlessness of liberated reason, metaphysical and religious arguments do not gain in importance. Quite the reverse: the poet observes the progressive secularization of the West. It manifests itself differently in the environment of the elites (he provides the example of Einstein here) and differently in wider social circles, as evidenced by emptying temples or nurturing of religious rituals as social traditions. In the circumstances outlined in this way, Miłosz dares - though not directly - to ask about the metaphysical reasons for existence, looking into the relationship between science and religion, which he will undertake again in The Land of Ulro. At that time, the defeat, as he defines it, takes on a form different from the way Wells understood it. He makes the following comment on this:

I think Wells' attitude is shared by more people than one might surmise from the timid and reluctant attitudes towards these issues. Far be it from me to disrespect the statements of modern physicists or such symptoms of literature as existentialism. Man vis-a-vis the world, deprived of his raison d'etre - this is the issue that comes to take the place of religion that is flowing away. What is more, we are beginning to deal with a sociological phenomenon here. (...) At any rate, Wells is an extension of the Renaissance, and the current mental crisis reiterates that crisis in a much harsher form, since we have behind us a century of unprecedented development of unrestrained research - a century ending with burning of books. ${ }^{375}$

Miłosz can see what is taking the place of religious and intellectual authority in America. It is puzzling whether and to what extent reading Wells inspired him to consider new forms of captivating the mind as a remedy for emptiness, and in the long run led him to the path of post-secular reflection.

Some of the continuation of his comments on Wells can be found in his account of Mann's lecture on Nietzsche, ${ }^{376}$ which Miłosz attended at the Library of Congress on April 29, 1947 - he writes about it in the 22nd issue of Odrodzenie. A decade before the release of Native Realm, Miłosz asks:

\footnotetext{
Many university students arrived at Mann's reading, as well as fat ladies in hats decorated with artificial flowers, sleeping sweetly through the entire speech, waking up just for the sake of saying that they do not understand anything and falling asleep again.

Someone, however, whose youth passed under the sign of Thomas Mann, had reason to listen carefully. Was it not the derailed descendants of Buddenbrooks who gave the world a
}

375 Ibidem.

376 The talk was published by the Library of Congress in the volume Mann, Thomas: Nietzsche's Philosophy in the Light of Contemporary Events, Washington: Library of Congress, 1947 and Mann, Thomas: Addresses. Delivered at the Library of Congress 1942-1949, Washington: Library of Congress, 1963. 
bloodbath? Was the dispute between Naphta and Settembrini from The Magic Mountain not the central dispute of our times? ${ }^{377}$

In the collection of essays of 1958, Miłosz will put Father Chomski in place of Naphta, and Adolf Rożek in place of Settembrini. This is a way of consistently illustrating to which participant in the dispute Miłosz credited with more strength and attractiveness. In his characterization of the Vilnius adversaries, however, the accents are arranged differently than it would appear from the American confessions. The author admits:

Here I repent: as for many of my contemporaries, the truly fascinating figure was the diabolical Naphta, a cynic and an ironist, a skeptic and a Jesuit, a supporter of fanaticism and violence. Settembrini merely aroused condescending sympathy. He was a liberal, declaiming on the victory of reason and faith in man. I do not think that this dispute is over. Naphta still has the power to attract the attention of supporters, both right-wing and left, while the good-natured liberal Settembrini scattered his ashes in the fields of concentration camps. ${ }^{378}$

Settembrini-Rożek, as well as Naphta-Chomski, are clearly distinct from the figures visible in the post-war landscape, and their dispute - jocular from the point of view of a Gymnasium graduate - in Native Realm is a conflict of arguments fundamentally different from what Miłosz meant in Odrodzenie. The fact that he was able to give a humorous tone to the Vilnius animosities shows how far he had traveled from Europe to America over the past ten years. In his account of the lecture, the values represented by Settembrini are described in terms of a tragic catastrophe, a defeat of reason different from that of Wells'. Wells' thought, projecting the laws of nature onto the world of civilization, bore no illusions regarding Settembrini's positive anthropology. The burial of Mann's liberal values affects Miłosz no less than his renunciation of religious and metaphysical justifications:

I repent for the second time. His words did not find any response in his contemporaries. In 1935, I listened to the deliberations of the Congress of Anti-Fascist Writers in Paris. Mann was one of the organizers. Günther, a young Nazi poet, was sitting next to me. ${ }^{379}$ And although I did not like to listen to Günther's remarks, spoken in poor French, in which sentimentality mixed with cruelty, I will admit with sadness that there was something that connected us: contempt for Settembrinis, contempt for the weakness of people discussing human rights without recommending any decisive and violent means to defend them. I never met Günther after that. Once I wrote him a card with a cynical joke. He was insulted, and this insult illustrates the division of people into two camps: some despised Settembrini with despair, others, like Günther, with triumph. ${ }^{380}$

377 Nowak, J. M., [Miłosz, Czesław]: Życie w USA, Odrodzenie 1947, issue 22, p. 5.

378 Ibidem.

379 Eten, Günther (1905-1942). German poet. On his contacts with Eten, Miłosz writes in more detail in Native Realm.

380 Ibidem. These dilemmas were shared by other European intellectuals with whom Miłosz could discuss these issues, for example Nicola Chiaromonte, who wrote: "Nihilism is the most conspicuous trait of contemporary life. Nihilism is sacrificing oneself for a cause one does not believe in, while 
At Mann's lecture, Miłosz found himself in a trap: he had a Settembrini in front of him, but one who took a risk, and who, upon losing all hope, settles his scores with those responsible for this state of things. The poet avoided Settembrini's choices not only out of fear of contempt, but because of the pragmatic conviction that they would lead him to self-destruction. Choosing life did not mean choosing to exist - the reader of Hegel and the addressee of letters from Kroński is once more reminded of this by Mann's lecture. In the series, Miłosz makes it clear that Settembrini's arguments are also his own. The means and the circumstances with which he might make them real, however, still seem to be out of his reach, which again leaves him no choice. Jarzębski subtly comments:

There is undoubtedly a manifestation of cynicism in "Dziecię Europy,” which has been repeatedly pointed out, but there is also a hidden, quite desperate, fear of the pain carried by the thoughtless and futile affirmation of traditional values. One needs to renounce them and, of course out of cold calculation, but also because it seems unbearable to stand by them..$^{381}$

For Miłosz, Settembrini's opponent is not Naphta then, but Joseph Conrad with his conviction that civilization is a fragile shell around the heart of darkness. Admitting his mental affinity with the writer, he shares the bitterness of his experience of emigration:

Yes, Mann may be accused of being a liberal, less naïve perhaps than his protagonist, whom he, as it often happens, provided with inferior arguments to his own, because Settembrini was closer to him. Mann always believed in the ultimate victory of reason and justice. He always spoke in a calm voice, not caring that the storm would drown out his words. If the word humanist is not an empty sound, then it is presumably so in relation to Mann. (...) Mann told in his letter the bitter truth about the emigrant's fate. He admitted that there were days when he envied the poorest people in Germany only because they could live in their own country. ${ }^{382}$

Under these circumstances, Miłosz listens with more appreciation to the arguments put forward by Mann, who, in his lecture on Nietzsche, presents the philosopher as the epitome of the fall of the German burgher culture, an unprecedented case of genius, whom mental illness deprived of the ability to self-reflect. At the same time, Mann clearly separated the views proclaimed by the philosopher from their Nazi

pretending to believe in it. Nihilism is the conviction that there is really nothing behind any faith or doctrine, and that therefore success alone matters. Nihilism is the identification of the good, the just and the true with one's personal interests. But where there is no shared spiritual order, the foundations of social living are absent; the life of society then becomes a question of force, politics a savage contest." In idem: “Nihilism,” politics 1945, May, pp. 138-139.

381 Jarzębski, Jerzy: “Obrazy Ameryki w Świetle dziennym Miłosza” [Images of America in Miłosz’s Daylight], op. cit., p. 297.

382 Nowak, J. M. [Miłosz, Czesław]: Życie w USA, Odrodzenie 1947, issue 22, p. 5. 
reception, denying also his alleged hostility to Judeo-Christianity. In his lecture, the author concentrates on the most moving issue: if Settembrini's voice seems too weak, Wells' self-knowledge leads to stoic pessimism, and traditional humanists are condemned to emigration, or at least internal emigration, on what foundations shall we rebuild the authority of reason? How to prevent the nesting of further insanities in the emptiness created after it is rejected? Miłosz, again, does not have much hope that Mann's criticism of the philosophy of life, his matter-of-fact analysis of Nietzschean philosophy in the context of the experience of war will find the right response. The time and place of the lecture is not without significance. The auditorium at the Library of Congress was filled with new encyclopedists, whose lack of experience made mutual understanding impossible:

These brave and intelligent youths applauded with enthusiasm all declarations on the rule of reason, and on the rational thought of the eighteenth century. These were close to them, because they have been reared in this tradition in schools. After all, all American struggles for liberation and the entire political philosophy derive from this. Yes, but these young people are the Settembrinis of 1910. Good-natured, naive and noble, unable even to reverse what is now happening in the Senate, a mere few steps from the library where the lecture is being delivered. The embittered and experienced Settembrini of 1947 speaking ex cathedra is something different - something else entirely. But at the same time he is dissimilar to the fanatical and cruel Naphta. ${ }^{383}$

Miłosz's account of the lecture should be considered in the broader context of the dialogue between Europe and America, questions about the common New World co-created on both sides of the Atlantic. Here one can perhaps see with most clarity what Miłosz means in his letters, when he mentions America's immaturity, and no sense of history in its people. On the one hand, he expresses aversion to the mercantile way of capturing reality. Życie w USA shows a picture of the Americans as guided by the principle of optimizing profit. The American, deprived of individual features, whose typological portrait can be built from elements scattered throughout the many episodes, is a homo oeconomicus. ${ }^{384}$ Even then, Miłosz poses questions about the ethical dimension of his activity, ${ }^{385}$ and this issue coincides with his reflection on

\footnotetext{
383 Ibidem.

384 This is addressed among others by Smith, Adam: An Inquiry into the Nature and Causes of the Wealth of Nations, London: W. Strahan and T. Cadell, 1776 and by Becker, G. S.: The Economic Approach to Human Behavior, Chicago: The University of Chicago Press, 1978; MacIntyre, Alaisdair: A Short History of Ethics: A History of Moral Philosophy from the Homeric Age to the Twentieth Century, University of Notre Dame Press, 1996.

385 There was a discussion in the USA in which the American and European perspectives were treated equally. See Weber, Max: „Class, Status, Party”. Translated and edited by Hans H. Gerth and Charles Wright Mills, politics 1944, September, p. 271-278; Weil, Simone: „Factory Work”. Translated by Felix Giovanelli, politics 1946, November, pp. 369-375.
} 
the meaning of Gulliver's Travels. ${ }^{386}$ The author learns with difficulty that the local foundations of social ties in America are different than those in Europe. This is the reason why to him America seems to be calculated in almost every sphere of life. On the other hand, as is also evident in the series, and in the articles published under his own name, that Miłosz is moved by disinterested gestures and acts of kindness of Americans, which he attributes to their idealism. He speaks most directly about this in his last correspondence, which creates the impression of a summary. The two final episodes are as much the culmination of the series as a confession of the difficulties with its continuation. They are separated - which seems significant - by articles published under the pen name Żagarysta and under Miłosz's own name. They concern Faulkner's work, celebrations of Independence Day, and the conference at Bread Loaf.

\section{Mitosz's Contradictions of American Capitalism}

In the last installment of the series, the author admits:

Driving through Harper's Ferry, where John Brown used to live, through Charles Town, where he was tried and convicted for treason, climbing the road through the wooded mountains, from where the expansive panorama of the Shenandoah River spreads out - I think that I have not written the truth about America so far, because it is a very difficult thing to do. I am thinking about how one would go about writing the chapters, separating the epithets. ${ }^{387}$

In an earlier issue, he admits under his own name: "For a long time I have been trying to discover the internal mechanism of the Americans and I am still failing at it." ${ }^{388}$ The last episode of Życie $w$ USA is formulated with rhetorical prowess. After the introduction, which is an account of a trip to the state of Virginia, the author proceeds to generalizations, in order to reveal the difficulties in formulating certain and unambiguous judgments about America. Each subsequent paragraph of this part begins with the words "a country," and it is worth keeping in mind "Moja piosnka II” [My Song II] by Cyprian Kamil Norwid as the negative context for this anaphoric series of statements. Why does the term 'nation' not appear here instead of 'country?' Did the author recall the Wilno lectures of Florian Znaniecki, and gave up using the European dictionary for describing reality that escaped its denotations? If so, did he know and follow the course of post-war discussions on American identity

386 Laurenz Volkmann also analyzes the critique of capitalism and lavish lifestyle in Gulliver's Travels in relation to Thomas More's Utopia and the category of homo oeconomicus. See Neoklassizistische Positionen gegen den homo oeconomicus. By the same author in: Homo oeconomicus. Studien zur Modellierung eines neuen Menschenbilds in der englischen Literatur vom Mittelalter bis zum 18. Jahrhundert, Universitätsverlag WINTER Heidelberg, 2003, pp. 608-644.

387 Nowak, J. M. [Miłosz, Czesław]: Życie w USA, Odrodzenie 1947, issue 48, p. 1.

388 Miłosz, Czesław: "Zabawy i spory” [Games and Arguments], Odrodzenie 1947, issue 44, p. 4. 
in academic and journalistic circles? It seems so. More than once, Miłosz critically discussed the Americans' self-portrait, a portrait in which they themselves later saw an excessive tendency to attribute uniqueness to themselves. ${ }^{389}$ The word 'country,' with its geographical connotations, offers more advantages to him than the political terms such as 'nation' or 'state.' It presupposes diversity, variability, coexistence of opposites, and is also close to his own spatial imagination. One may also presume, although the author diplomatically omits this issue, that as a witness of discrimination and racial segregation, the difficult situation of Native Americans and the new immigration, he does not see the Americans as a community fused by historical and cultural experience (the state of Virginia, where the correspondence originated, was traditionally seen as the boundary of the so-called Black Belt). In the post-war years, movements for the equality of various groups in the United States were only in their incipient phase, and so it is easier to understand why the correspondent abandons altogether the notion of 'nation' in his description. ${ }^{390}$

At the foundation of his text lies a combination of anti-institutional and dialectical thinking. Miłosz consistently rejects in America the sphere of public actions as the source of alienation and unification:

A country of enormous mental apathy, mental sleep. Living machines, laughing, working, reproducing, living dolls with a completely mythologized brain; indeed a tribe of the machine age. (...)

A country with an amazingly smooth operation of the social machine, with a uniform upbringing of the average citizen. (...)

A country of myths and taboos, a country of thoughts in pincers. A wise man in a private conversation changes when he takes the stand at the university lectern. Insipid water of generalities, boredom resulting from a fear of involvement and insulting the commonly accepted taboos - that is all. (...)

A country of hard struggle for existence for the individual, completely indifferent to those who slide down, one that values only the successful, ruddy and smiling, and shows contempt to those who believe they have higher qualifications than the job they do. (...)

A country with a great deal of religion and a multitude of temples, but quite pagan, because religion is only a ritual of social communion, something to participate in, like going to football games. (...) Religion as charity work, the church as a meeting place for neighbors, an institution as lasting as the institution of gathering for a game of bridge or a dram of whiskey. Not even the fiercest of American atheists would be able to accomplish such a complete destruction of metaphysics. (...)

A country with the agility of a bear in foreign policy. (...)

A country with a backbone broken by a technical revolution. (...) $)^{391}$

389 On this, see Globalizing American Studies. Edited by Brian T. Edwards and Dilip Parameshwar Gaonkar, Chicago: The University of Chicago Press, 2010.

390 Homi K. Bhabha talked about this in the lecture Living Side by Side. On Culture and Security. Inaugural Global Thought Lecture, Columbia University, April 29, 2013. https://vimeo.com/67419752 Date of access: June 8, 2018.

391 Nowak, J. M. [Miłosz, Czesław]: Życie w USA, Odrodzenie 1947, issue 48, p. 1. 
Miłosz formulates even more critical remarks, at the same time referring to American attempts to specify the country's own identity:

There is nothing left of the old America, nothing of the feelings, nothing of the beliefs, nothing of the morals. Production of cinematic myths about the history of the United States will not help here. Everyone knows that these are only legends, because in fact there is no tradition, only absolute emptiness. Hence the desperate clinging to myths and taboos, the constant desire to be American, all the greater since no-one knows what it really means. ${ }^{392}$

Aware that he will find arguments against his reasoning, he provides them himself:

A country of excellent efficiency, ability to work, and flexibility, boasting of being able to adapt to any conditions and accomplish in several years that for which other nations need a century. ${ }^{393}$

The correspondent situates himself on the outskirts of the mainstream of American values, and displays the positives that appear most valuable to him. Against the destructive principles of collective life, he sets the features and forms of mentality appropriate to individual people, and to single and peripheral activities. He continues in the same anaphoric convention:

A country with an enormous number of deeply kind people who find a vent for their religious longings in their actions for the benefit of others, are ready to go to distant countries, in the most difficult of conditions, to help, cure, teach with only one thing for payment - a sense that they are useful to others. These people of good will deserve the highest homage, for they are the salt of America. ${ }^{394}$

The opposite pole of his criticism is compassion - Whitmanesque solidarity. It dictates bitter conclusions about the consequences of the American organization of life:

A country with ever-growing numbers of insane people. I think the reason here is a lack of intellectual and emotional pressure in the atmosphere. Can man live in emptiness? Do deepwater fish thrown onto the surface not die? A soft car, a soft neat and tidy interior, a monotonous life - money, wife, children, nothing for the mind, nothing for the feelings - until one day one slits one's arteries, demolishes the neat and tidy interior, and a straitjacket is slapped on one very promptly. ${ }^{395}$

Miłosz presents America as a place where democracy only apparently ensures the free functioning of alternative and competing cultural values. He argues that society is shaped according to the principle of power adopted here, regulating all aspects of

392 Ibidem.

393 Ibidem.

394 Ibidem.

395 Ibidem. 
public life. He describes a certain type of man who has a chance to succeed and deserve recognition, if he renounces all desires contrary to the collective ideals. If, as Bell would write later, modern society is an amalgam of three realities, i.e. the social structure, or more precisely techno-economic order, politics, and culture, Miłosz observes to which values they are distilled, and what kind of man they produce, when the distinctly American ratio becomes the driving force of his actions. He precedes Bell's intuitions, taking note of a lack of metaphysical and religious legitimacy for human efforts and aspirations, and over-emphasis put on collective life in comparison to individual aspirations. In lieu of the former transcendental sanctions, a void appears that is best not thought about - hence, he believes, the common aversion to independent, critical thinking and all the numerous ways of filling that void. Miłosz comments: "In America - said an American intellectual - the principle that religion is opium for the people loses all relevance. Here the cinema is opium for the people." ${ }^{396}$ The distressing experience of emptiness as a result of the triumph of the ratio that ultimately leads to nihilism is, in his opinion, the immediate cause of insanity, and to prevent it is necessary to produce new myths and legends of compensatory significance.

The author situates American society between the poles of cultural taboos and myths. Most interesting seems to be his observation regarding the taboo on critical thinking - the claim that it is reserved for a tightly knit group of specialists is in line with earlier remarks made by Georg Simmel, who characterized the directions of development of a modern metropolis. Miłosz dissects the image of America that Poles harbor, with its myths of equality, freedom and economic liberalism. In particular, it seems interesting that the recent criticism of the free market, abolition of price control and the OPA, whoever predicts the collapse of the economy drifting in an unpredictable direction, also gives up the conviction that the American economic model is based on liberal principles. This illustrates how Miłosz's image of America had clarified, and how many observations he needed to retract before he discovered the real contour of the reality there. He deepens his recognition of the oligarchic democracy, a bigcity regime, a command center for which he tries to find a counterbalance in the peripheries - the true provinces where he travels and which he portrays colorfully in several episodes. Only they have positive connotations in his dictionary - very much unlike metropolises:

America is a province. A ruddy, milky, jovial province. All of its big cities, except New York, are also provincial. A province with skyscrapers is also possible - for example Chicago. A well-built, and even over-nourished breed of provincials, benefiting from the achievements of technology, populates this continent. A provincially mechanized breed. ${ }^{397}$

396 Nowak, J. M. [Miłosz, Czesław]: Życie w USA, Odrodzenie 1947, issue 48, p. 1.

397 Nowak, J. M. [Miłosz, Czesław]: Życie w USA, Odrodzenie 1947, issue 46, p. 4. 
Earlier, he writes, "America is primarily thousands of small provincial cities." ${ }^{398}$ In the series, Miłosz uses the term "province" in its territorial and metaphorical sense. Geographical provinces attract him as they did in his student days, in the land of forests and lakes. He is fascinated by the exoticism and exuberance of nature. Interestingly, it is his articles rather than poems from that period, that contain more images of local landscapes. However, these images always have utility value - they may serve as an introduction, an outline of the background and context, or an attractive segue into anthropological and sociological arguments.

His sense of enchantment with the landscape is exhausted upon encountering the residents of the provinces. On the one hand, the author sympathizes with their plight, and manifests all forms of sympathy for their morals, culture and customs. Sometimes he shares in their entertainments. The poet sitting at the table in the American countryside is not very different from the winner of the Nobel Prize winner, feasting in his homeland.

At the same time, Miłosz sees the residents of the provinces as victims of the manipulation of power exercised from command centers, ostensible democratic participants deprived of real causative power, people living beside the course of history, whose consciousness is immersed in a dream. He considers the idyllic nature of the village and the small town manifestations of American internal isolationism all the more dangerous, since they are based on trust in power and in moral and civilizational superiority over the rest of the world. He deconstructs the idea of the American power structure in one of the final episodes of the series, which differs from all the other episodes due to its epistolary form. It is a letter addressed to a girl named Zosia, and one may wonder whether this choice of name is accidental, or whether it refers to the tradition of Polish Romanticism which, after all, had a particular affection for it. In the episode, Miłosz lays out his theory of center and periphery as a system regulating life in America. Taking Rome and the Roman Empire as reference, he presents the virulent characteristics of the center:

\footnotetext{
These well-dressed children going to school are brought up in the belief that their country is the best, the happiest, and one must infinitely regret those who have not attained the honor of becoming its citizens. The center has priceless libraries, art galleries, and kind-hearted humanitarians who, with the use of learned arguments, prove what the humanity has gained by creating such a nation. The essence of the center is a clear conscience and a certain mutual kindness of all those who belong there. ${ }^{399}$
}

398 Nowak, J. M. [Miłosz, Czesław]: Życie w USA, Odrodzenie 1947, issue 1, p. 7. It is worth mentioning that at that time The Nation published series of articles in the section titled Small Town America.

399 Nowak, J. M. [Miłosz, Czesław]: Życie w USA, Odrodzenie 1947, issue 31, p. 1. 
The ironic backdrop of these statements is American exceptionalism that Miłosz negated, regarding it as the main source of the mind's deceptions and enslavements. ${ }^{400}$ Opposite the center outlined in this way, the dirty provinces are placed. They already start in the poor districts of big cities. In this interpretation, the awareness of a representative of the center is somewhat reminiscent of the mind of Rodion Raskolnikov, striding through the streets of St. Petersburg - he commits the similar error of identifying aesthetics with moral purity. The opposition of cleanliness and dirt was chosen very aptly. Between the lines, Miłosz says that the opposition of center and periphery, shown as the relation between cleanliness and dirt, also captures the relationship between white and non-white America. In this context, it is easy to predict that the relations described here between the center and periphery include discriminatory practices, domination, and exploitation. The author knows how difficult it will be for him to persuade the reader: "The myth of America - moving on seems to consist in the fact that one speaks of its center, forgetting its periphery. It is a very large center." ${ }^{201}$ He examines the subject of subjugation using examples of social structures and attitudes towards people of races other than white. In presenting the social hierarchy in the United States, from the patrician families educated at Harvard and living in New England, or - as he calls them - the "brahmins," to the "bumpkins," farming the land in the South, he draws attention to the fact that one's position in society here results mainly from one's material status, but also from belonging to the "center," which entails sharing the values created by the dominant social stratum. Belonging to the "center" is made possible through the education system, which grants one passage into public life, just as it imposes the view of reality typical of the privileged class of citizens:

As for the peasants, it is necessary to distinguish the South, where there are significant numbers of poor and primitive tenant farmers, but in most parts of the country the predominant type of farmer, who differs from the traditional "bumpkin" in that he belongs to the center and not to the periphery. Universal education (perhaps not so much education, as raising a uniform type of citizen at the same moral level) pushes the periphery further away. There are horrifying slum districts, there is misery. Well, whatever else... But most white Americans form the center and this is probably the source of the attractiveness of America. Of white people. ${ }^{402}$

Unwilling to join the national discussions on racism in the United States, Miłosz makes the following reservations:

400 A very interesting critique of American exceptionalism, close to Miłosz's own position, is presented by Pease, Donald E. in "American Studies after American Exceptionism? Toward a Comparative Analysis of Imperial State Exceptionalisms." In Globalizing American Studies. Edited by Brian T. Edwards and Dilip Parameshwar Gaonkar, Chicago: The University of Chicago Press, 2010, pp. 47-83.

401 Nowak, J. M. [Miłosz, Czesław]: Życie w USA, Odrodzenie 1947, issue 31, p. 1.

402 Ibidem. 
Do not suspect me of a special tenderness towards the Negroes. I have seen so much human suffering, sometimes it would seem impossible to bear, that my heart has hardened - because I must always compare. I have already written in my correspondence that talking about hundreds or thousands of lynchings a year makes no sense. ${ }^{403}$

The point, in fact, is different entirely: Miłosz poses and considers the issue of quasicolonialism in America. ${ }^{404}$ He recognizes the social nuances that divide people into us and them. This division, he notes, is subtler and runs deeper than would be evident from observing of ethnic and racial minority districts in metropolises; it has a larger territorial range and runs along the lines of diversified values in many regions. The divide also affects the neighboring countries, toward which, as Miłosz points out, the United States has been pursuing an imperial policy:

Yes, the center of America is huge, strong and alluring. Let us not forget, however, that the periphery is not only the Negroes and not only the South, which has not yet risen from Reconstruction, or wild exploitation by the North's Capital after the Civil War. The periphery of the United States is all of Central and South America, the entire landmass. Today, when so much is being said about the "Western Hemisphere" and American unity, one should not disregard it, because the US has the entire land in its hands (except maybe for Perón) which it reigns supreme. The domain of the barefoot and uneducated peasant begins already in the nominal US properties, such as Puerto Rico, not to mention Mexico, Nicaragua, or Brazil. Using my method of judging a state not by the theory taught to a boy in the center, but according to what is the "heart of darkness" of his country, of which no one will tell him - this is worth thinking about seriously. ${ }^{405}$

Paradoxically, thanks to these observations and readings of American literature, Miłosz finds his own place on the mental map of the United States - he is among those who have chosen the perspective of the periphery, and from this position they attempt a peculiar decentralization of America:

The strength of the American center is that it contains the righteous, who harass his lethargic conscience. Among the righteous, the writers have the first place. Writers, as you know, can be divided into good ones and bad ones. Without going into the subtleties of aesthetics, I will communicate to you the observation that bad writers are those who are stuck in the center, without leaning their noses out into the periphery. They provide people in the center with the blissful belief that everything is developing brilliantly. Good writers are those who have the courage to talk about the periphery - and it is interesting that the best American writers are simply peripheral - both in their origins and in their range of topics. In fact, the center should build a great gallows and hang such a Caldwell or Faulkner, or lock them up in the hole - let them rot, damned bastards, for dragging such matters out into the light. I'm surprised

403 Ibidem.

404 Cf. Bhabha, Homi K.: Side by Side, op. cit.

405 Nowak, J. M. [Miłosz, Czesław]: Życie w USA, Odrodzenie 1947, issue 31, p. 1. 
they have not done this and instead sell Caldwell's chilling stories at 25 cents apiece at every newsstand..$^{406}$

By design, that the final episodes of Życie w USA are adjacent to Miłosz's essay on Faulkner, with flattering statements about Caldwell - under their influence and following their example Miłosz assumes the peripheral perspective as the future author of The Issa Valley and Native Realm. His irony in the comment about the freedom of American critics of the center has a clear Polish political subtext. Reflection on American colonialism gives him the opportunity to reflect on the centralization and monopolization of power in general. Through his generalizations, which he rhetorically endows with playfulness, or characteristics of a work in progress, he smuggles in his criticism of a totalitarian system that does not refer to the realities across the ocean. Here he uses the metaphor of an avalanche, so as to depict the influence of the individual on history. He reveals his solidarity with the human being who suffers harm from cruel policies. Here, to put it plainly, springs the source of Traktat moralny [Treatise on Morals], which Miłosz was finishing as the last episodes of Życie w USA were printed in Odrodzenie:

You see, Zosia, before the war I lived for many years in the Polish province. Ministers, lofty dignitaries and poets drinking with them were inaccessible social heights for me. Then I learned that a small person from the periphery means much more than a voivode or minister. The fact that this little man means nothing is only an illusion. Please note how delicate this mechanism is. The one who cannot raise his voice in his defense has been wronged. Ten, a hundred, a thousand, one hundred thousand, a million such people have been wronged. This cannot be hidden (it never succeeds) and awareness of these facts permeates into the center, which, as you know, likes to have a clear conscience, or at least be in harmony with logic. What happens then? A multiplication of center theories, slogans and actions meant to conceal or decorate these facts. Theories only half a degree away from reality, slogans that are dangerous, actions that are slightly contradictory to common sense. Social life, however, is governed by the law of avalanche. This is how the center's aberration slowly develops, and it will, believe me, one day express itself in some insanity, inconceivable to the people standing outside and not subjected to center's pathogens. Were not the little people from the periphery, the residents of Warsaw during the war, astonished by the insane moves of the Third Reich? They must have been amazed because they were unfamiliar with the temperature at which the German center was living. ${ }^{407}$

What are we talking about? After all, not about America and not about Nazi Germany... This statement, or perhaps even the entire final episode of the series, is a gloss to Traktat moralny [Treatise on Morals]. The idea expressed here about the inevitable aberration of the center - and not just the American center - is the point here. It is a good illustration of the place where the poet had found himself intellectually and

406 Ibidem. John Steinbeck wrote about English-language writers in a similar vein. In idem: A Russian Journal. With Pictures by Robert Capa, New York: The Viking Press, 1948, p. 164.

407 Nowak, J. M. [Miłosz, Czesław]: Życie w USA, Odrodzenie 1947, issue 31, p. 1. 
spiritually. It helps to understand why he decided against continuing the series in his ambiguous role of a correspondent writing under a pseudonym. This is his first symbolic transition from a position within the center, symbolized also by holding a post in the diplomatic service, to a peripheral position. This is the moment when perhaps the poet found a makeshift settlement of the dispute between Naphta and Settembrini - in a way somewhat akin to Castorp. Miłosz rejected Naphta’s cynicism, whose self-irony lined the poem "Dziecię Europy" [Child of Europe]. Nor was he attracted by Settembrini's idealism, in Mann's version or America's, epitomized by young humanitarians from the "center" who profess their faith in their own uniqueness. In his own way, he set himself free from the trap of ideas that cannot stand up to reality. He had several guides through the maze of contradictions. Undoubtedly, they included the peripheral writers, with Faulkner in the lead, and the arbitrator in the dispute between Mann's adversaries for him was Joseph Conrad, one of the patrons of Traktat moralny [Treatise on Morals].

\section{Reception of the Series Życie w USA}

Życie w USA was read on both sides of the Atlantic. ${ }^{408}$ The national literary community quickly realized who was hiding under the pseudonym Jan M. Nowak. The series was not without its critics, among whom only Stefan Kisielewski came out officially. As Jacek Natanson recalls:

Odrodzenie was not really neutral; throughout the Krakow period there were ongoing polemics with Tygodnik Powszechny, especially in almost every press review attacking this bastion of Catholicism. ${ }^{409}$ The chief polemicist in Tygodnik Powszechny was Kisielewski, who missed no opportunity to attack the collaborators of Odrodzenie. ${ }^{410}$

Kisielewski criticized Miłosz's departure from the country in a column titled "Nie bądźcie szczurami” [Do not be like rats]. He did place Miłosz among other emigrants, nonetheless he appealed:

The poet Czesław Miłosz, columnist Mieczysław Wionczek, and composer Tadeusz Kassern are in New York - each of them performs some function there, related to the propagation of Polish culture. The writer Ksawery Pruszyński is in Washington. The poet Jerzy Putrament is an envoy to Switzerland. Irena Krzywicka is in Paris, the poet Zbigniew Bieńkowski and critic Artur Sandauer went to Paris. Jerzy Zagórski, a publicist, is going away to Belgium, France and Italy

408 Manfred Kridl's archive contains press clippings of articles signed with the poet's name and his pen-names. Among them there are also installments of Życie w USA. See Manfred Kridl Collection, Columbia Rare Book and Manuscript Library, Box 20, Folder 3.

409 Natanson, Jacek: op. cit., p. 117.

410 Ibidem, p. 119. 
for a long time. Edmund Osmańczyk is constantly in Germany. And so on and so forth. People are continually leaving on more or less important missions, everyone is constantly 'driven' to go abroad. Away they run like cats with blisters or bells at their tails. Cui bono?

I am also constantly being nagged by friends: Are you leaving? Would you leave? Do you want to leave? Well, I will reply to everyone: no, no, no! I am not leaving, I do not want to leave, I have no intention of leaving, I do not think that one should leave. In Poland it is much more interesting than abroad; Poland today is the liveliest, most interesting country in Europe, a country where the problems and conflicts bothering the world manifest themselves the most. The internal front in the country, the front of labor and reconstruction requires people, and at same time these need to be creative, intelligent, pioneering and courageous people. It is necessary to rebuild the culture destroyed by the occupier, threatened in its existence - in the first place, we need artists, writers, and politicians - we need brains. Let us also remember about the outflow of blood that we suffered through permanent 'London' emigration - as part of it, many eminent writers and scholars whom we would love to see with us in the country remained abroad. Miłosz, Kassern \& Co went to promote Polish culture abroad - but to promote something, first you need to have it. Before the war, there was the Academy of Literature in Poland, consisting of beautiful figures. And try to create an Academy today with writers staying in the country! What cucumber salad it would be! (with vinegar and sour cream, to be sure, but no pepper). We have almost nothing - everything has to be made anew. However, this is not hopeless effort - quite the contrary, I think it is very rewarding. Poland will be the way we create it, it is all up to us. We believe in it, let us get rid of the inferiority complex, as dangerous as national megalomania, let us get rid of morbid pessimism, as poisonous as naïve optimism. Let us look on the progress we have made over the past year - how many things have changed for the better. The atmosphere in the country depends on us. Progress is possible, that much is certain, but we must really want it, we must believe in it, we must fight for it - we must believe in Poland and its vital forces. And above all - we need to refocus our strengths - not scatter them about in unnecessary voyages. I understand that Zagórski's trip had a purpose - this astute, keen journalist will bring us from the West more than one valuable synthesis, more than one creative, imposing look at the postwar reality of Europe. I understand that Bieńkowski or Sandauer went to Paris for several months to confront the Polish poetic laboratory with the achievements of new poetry in the dethroned "capital of the world.” But whatever is Czesław Miłosz staying in New York for? He has lost touch with Polish reality - this is evident in his clichéd, narrow-minded, biased article in Przekrój, wholly unworthy of the intellect of his measure, ("Polska z Nowego Jorku" [Poland from New York City] - No. 66). We have five or six poets of a higher caliber - we cannot afford the luxury of losing even one of them. Gentlemen - do come back to the country! Do not become pessimists, or rats! The Polish ship is sailing on, Polish politics has many achievements - although it may look different to the poet from the perspective of New York. The Polish ship will keep sailing steadier and steadier, in an ever brighter direction - this depends only on us - believe me, there is a great deal to do. But for this you need people, people with brains, authority and courage. So do not leave the country - and whoever has left, let them come back. We cannot afford to scatter! ${ }^{411}$

Kisielewski's column appeared before Odrodzenie began to print Życie w USA. Miłosz formulated an answer to the allegations and sent it to Kuryluk with a request that it be published. It was an abridgement of a very elaborate and emotional response. ${ }^{412}$ Upon

411 Kisielewski, Stefan: “Nie bądźcie szczurami” [Do Not Be Like Rats], Tygodnik Powszechny 1946, issue 71, p. 8.

412 See Miłosz, Czesław: “Do Kisiela” [To Kisiel], Beinecke Library, Box 113, Folder 1609. 
reflection, the poet withdrew the text. It contains a harsh criticism of the intellectual atmosphere of the national elite, as well as some intuitions developed later in the famous No.

Kisielewski read Życie $w$ USA and in the columns he referred to the arguments made by Jan M. Nowak. He never revealed if he had guessed who was hiding under the pseudonym. In the commentary to the last episode, he wrote:

Odrodzenie has for some time now been publishing correspondence from the United States, written by a Mr. Jan M. Nowak - correspondence which, both in its rich information content and objectivity, and in its refined literary form, is far from the various demagogic pseudo-reportages, such as those fabricated "upon request" by Mieczysław Wionczek. In his latest correspondence, Mr. Nowak said that the vast majority of white US citizens live in prosperity, and that this happens at the expense of the work of Negroes and South American nations, with the sole exception of Argentina. Latin American nations, says Mr. Nowak, are in economic captivity to the United States, which does not allow them to expand their own industry, but forces them to buy products "made in the USA," thus extracting their living juices them from. ${ }^{413}$

Speculations about the possible collapse of the totalitarian center did not capture the columnist's attention. He included Miłosz's voice in the national discussions about the collapse of colonial powers and the abolition of global economic slavery. This in turn raises the question to what extent the readers of the series were able to read the intentions of the author hidden in generalized formulations, working hypotheses, and jocular associations.

Kisielewski did occasionally respond to Miłosz's impertinent remarks, and Miłosz himself did not avoid personal comments either. After he provoked the authors from the circle of Tygodnik Powszechny, ${ }^{414}$ Kisiel gave the following acerbic reply:

In the same issue of Odrodzenie, Mr. Jan M. Nowak in correspondence with America warns us against the barren, boring American emptiness; he claims that if I were to be sent to America, I would start writing oratorios in honor of Gomułka. Mr. Nowak is wrong - not about the oratories - it's not out of the question - but about my alleged illusions concerning America. I do not doubt that the psychic climate of this country, only just building up its tradition and culture, does not suit me - that is why I would not stay there. But the fact that I can imagine the American boredom perfectly well does not prove that I have to close my eyes to the boredom of home. I see the tragedy of Europe in its desperate defense against the offensive of multiple, total boredom. The paroxysms of France, the hardships of England - these are the convulsions of the culture of the old continent threatened by boredom. Neither Americanism nor Marxism will help here - it must find a cure in itself, in its spiritual attitude built over centuries. ${ }^{415}$

413 Kisielewski, Stefan: "Pod włos...” [Against the Grain], Tygodnik Powszechny 1947, issue 127, p. 8.

414 See Nowak, J. M. [Miłosz, Czesław]: Życie w USA, Odrodzenie 1947, issue 48, p. 1.

415 Kisielewski, Stefan: "Pod włos...” [Against the Grain], Tygodnik Powszechny 1947, issue 43, p. 8. 
The polemics between Kisielewski and Jan M. Nowak are the only trace of the official reception of Życie w USA. This is symptomatic both from the perspective of Miłosz's work and the history of the literature of Polish People's Republic. The poet does not return to it in his memoirs or in extended interviews. He neither reprinted the series nor did he include it in any of his later books. 